\title{
Climatic and geographic patterns of river runoff formation in Northern
}

\section{Eurasia}

\author{
Alexander Onuchin ${ }^{1}$, Heiko Balzter ${ }^{2}$, Helen Borisova ${ }^{1}$ and Eleanor Blyth ${ }^{3}$ \\ ${ }^{1}$ V.N. Sukachev Institute of Forest, Siberian Branch Russian Academy of Sciences, \\ Academgorodok, 660036 Krasnoyarsk, Russia, Tel. +7 (3912) 494 650, Fax. +7 (3912) 433 686, \\ email: onuchin@ksc.krasn.ru \\ ${ }^{2}$ Climate and Land Surface Systems Interaction Centre, Centre for Ecology and Hydrology \\ (CEH) Monks Wood, Abbots Ripton, Huntingdon, Cambridgeshire, PE28 2LS, UK, Tel: +44 (0) \\ 1487772400 Fax: +44 (0) 1487 773467, email: hbal@ceh.ac.uk \\ ${ }^{3}$ Centre for Ecology and Hydrology (CEH) Wallingford, Maclean Building, Crowmarsh Gifford, \\ Wallingford, OX10 8BB, UK, Tel. +44(0)1491 838800, email: emb@ ceh.ac.uk
}

Keywords: river runoff; land use; Siberia; river discharge; climatology; permafrost

\section{Abstract}

Siberian rivers are of global importance as they impact on the freshwater budget of the Arctic Ocean, which affects the Thermo-Haline Circulation in the North Atlantic Ocean. Siberian rivers, in particular the tributaries to the larger rivers, are under-represented in the international river-regime databases. The runoff of three Russian rivers in the Central Siberian taiga (Kureyka, Karabula and Erba) is modelled to analyse the relative influence of climate. In addition three rivers (Rhine, Maas and Odra) in Western Europe are similarly assessed as a control. The results show that the role of precipitation and autocorrelation as factors in the formation of river runoff is stronger under oceanic climate conditions, increasing from the central regions of Northern Eurasia towards the Arctic Ocean in the North and the Atlantic in the West. At the same time the influence of summer temperatures is weakened. The formation of Northern Eurasian river runoff appears to be influenced by periodically thawing top horizons of permafrost soil. Time served as an indicator for land use change after inclusion of meteorological data in the models. Maas and Erba showed a significant influence of the time factor. For the Erba the onset of agricultural land use in the catchment coincides with a drop in runoff. A similar 
causal relationship is suggested for the Maas. Land use can change the formation of runoff, which in turn can be used as an environmental indicator for sustainable land use.

\section{Introduction}

River flow is of central importance to many human activities. The need to study river runoff and the causes of any changes is required by catchment managers and environmentalists needing integrated assessments of terrestrial ecosystems. Siberian rivers, in particular, are underrepresented in the international river-regime databases (Gustard and Cole, 2002). For local catchment management assessments this gap needs to be filled.

Siberian rivers influence the freshwater budget of the Arctic Ocean, which affects the Thermo-Haline Circulation in the North Atlantic Ocean (Rahmstorf, 1996). The three large northern flowing Russian rivers Ob, Yenisey and Lena produce on average $46 \%$ of the total runoff to the Arctic Ocean (Lammers et al, 2001). River discharge into the Arctic Ocean from the largest Northern Eurasian rivers increased by $2 \mathrm{~km}^{3}$ per year between 1936 and 1999 (Peterson et al. 2002). This increase was correlated with changes in the North Atlantic Oscillation Index (NAO) and global mean surface air temperatures (Peterson et al. 2002). There has been a slight increase in runoff in the late-1970s for other rivers in European Russia and western Siberia, especially in winter and spring (Grabs et al 2000; Shiklomanov et al 2000). The reasons for these increases are not entirely clear. Climate warming would impact the river flow by producing an earlier snowmelt, which would increase the spring river flow and by decreasing the permafrost, which would increase winter flow. This has been demonstrated by Yang et al (2002) in a study of the Lena River, which is experiencing a change in its hydrology due to climate change that is affecting the permafrost. Yang et al (2004a and 2004b) also studied the Yenisey and $\mathrm{Ob}$ rivers to identify the natural verses the man-made changes to the river flow. Natural changes were statistically significant in the upper reaches of the rivers, but regulations (dams and irrigation) meant this signal was lost and even reversed at the basin outlets. Berezovskaya et al (2004) analysed the Ob, Lena and the Yenisey but found incompatibilities between observed precipitations and river flow. They concluded that there was uncertainty in the data as well as the perceived factors impacting runoff change. A recent study by McClelland et al (2004) showed that permafrost thaw, dam regulation and fires could not alone explain the observed increase in river flow.

Clearly, there is some uncertainty in hydrological modelling of high-latitude river systems that must be resolved before the risk of changes to the Arctic Ocean freshwater budget can be quantified (Carmack, 2000; Prowse and Flegg, 2000). 
River flow is not only influenced by climatic change but also by land-cover change (De Roo et al. 2001), both anthropogenic and natural. Anthropogenic land cover change due to agriculture and sylviculture have occurred during the studied time period in some of the catchments studied here, and an analysis of the runoff data can show its effects on the river runoff. Van der Ploeg and Schweigert (2001) concluded that the Elbe flood peaks, recorded since 1950, are related to the changes in postwar agricultural land use in former East Germany. Single fields on collectivised farms became increasingly large and were cultivated with increasingly heavy machinery leading to large-scale enhancments of surface runoff in periods with prolonged and excessive precipitation (Van der Ploeg and Schweigert 2001). Pfister et al. (2004) documented that land use change, particularly urbanization, can have significant local effects on flooding in small basins especially during heavy local rainstorms, but no evidence exists that land use change has had significant effects on peak flows in the large rivers Rhine and Meuse. Pfister et al. (2004) found only a very limited effect of changes in land use on the discharge regime for the main branches of the Meuse and Rhine rivers, but state that for mesoscale basins, future changes in peak flows will depend on the changes in the variability of extreme precipitations in combination with land use changes. Natural changes to the land cover in this region may be significant in the future (Harding et al, 2002). A northern migration of forest is expected to occur in this region over the next century due to warmer climates, which favour taller denser vegetation (Callaghan et al, 2005). There would be a positive feedback on warming the climate from this darker land-cover (Betts, 2000 and Viterbo and Betts, 1999). 
Three Russian rivers (the Kureyka, the Karabula and the Erba,

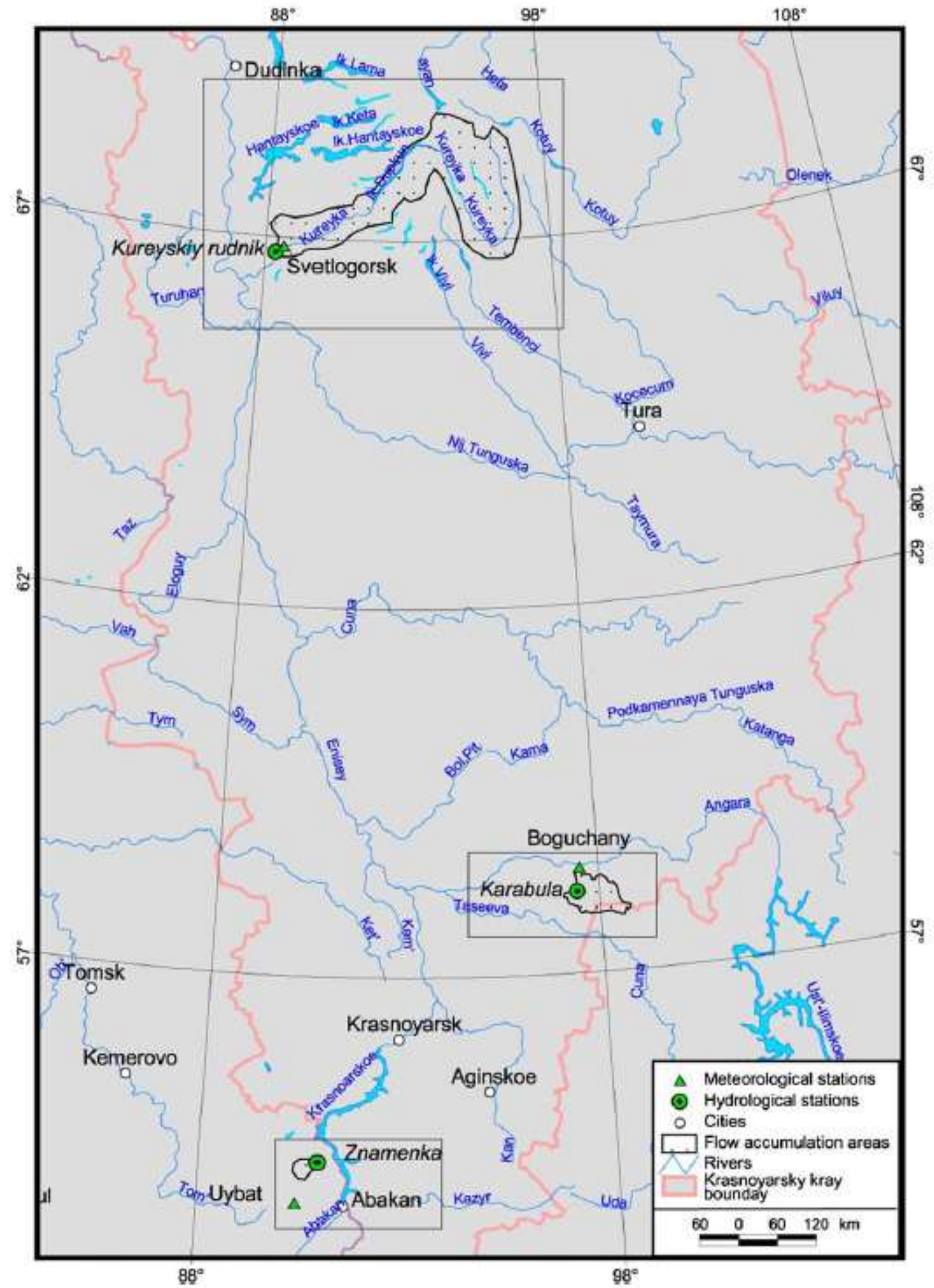

Figure 1) are studied in this paper to analyse the relative influence of climate and landcover on their hydrological regimes. In addition three rivers in Western Europe are similarly assessed as a control (see Section 1 and 


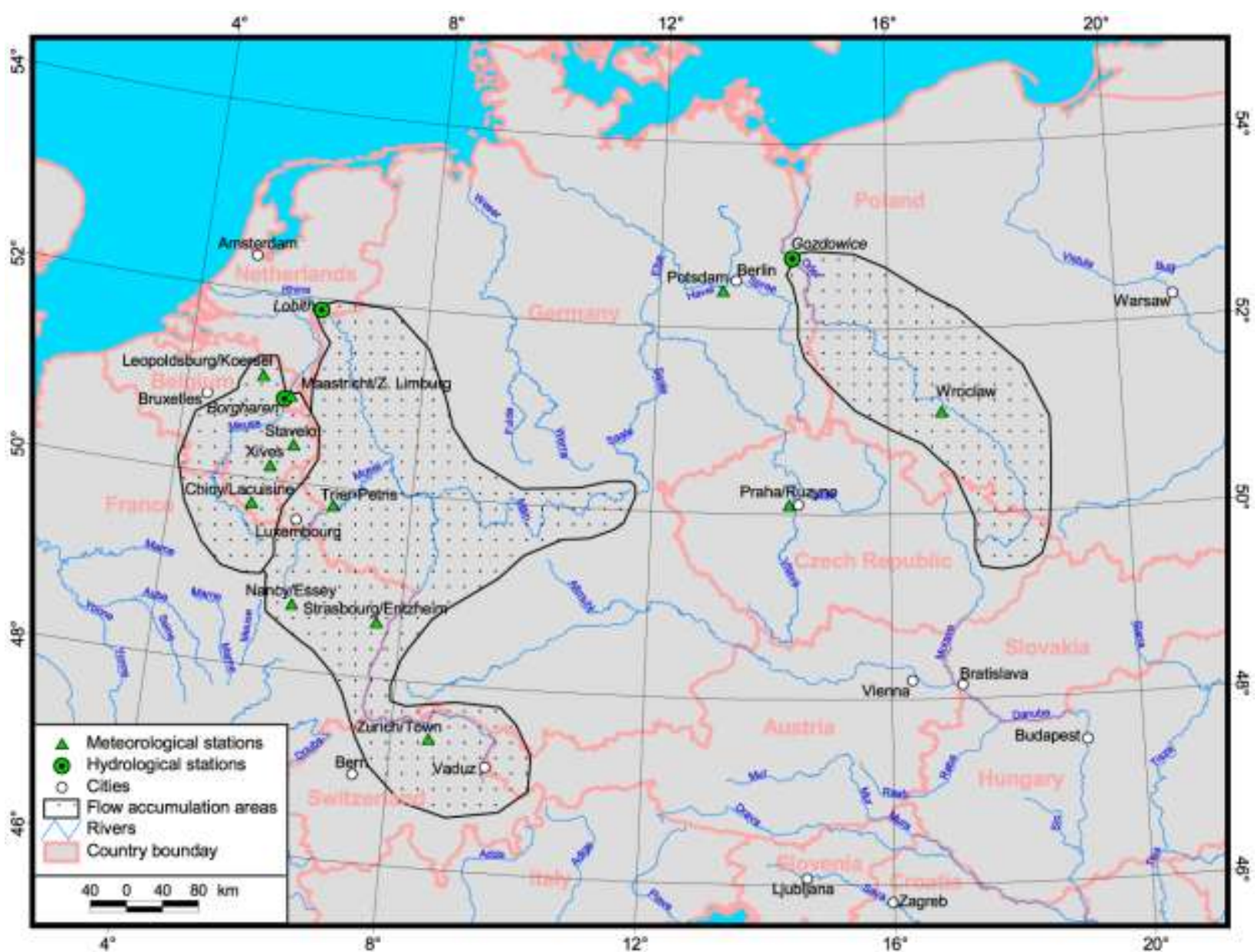

Figure 2 for details of these rivers).

The

catchment

of

the

Kureyka 


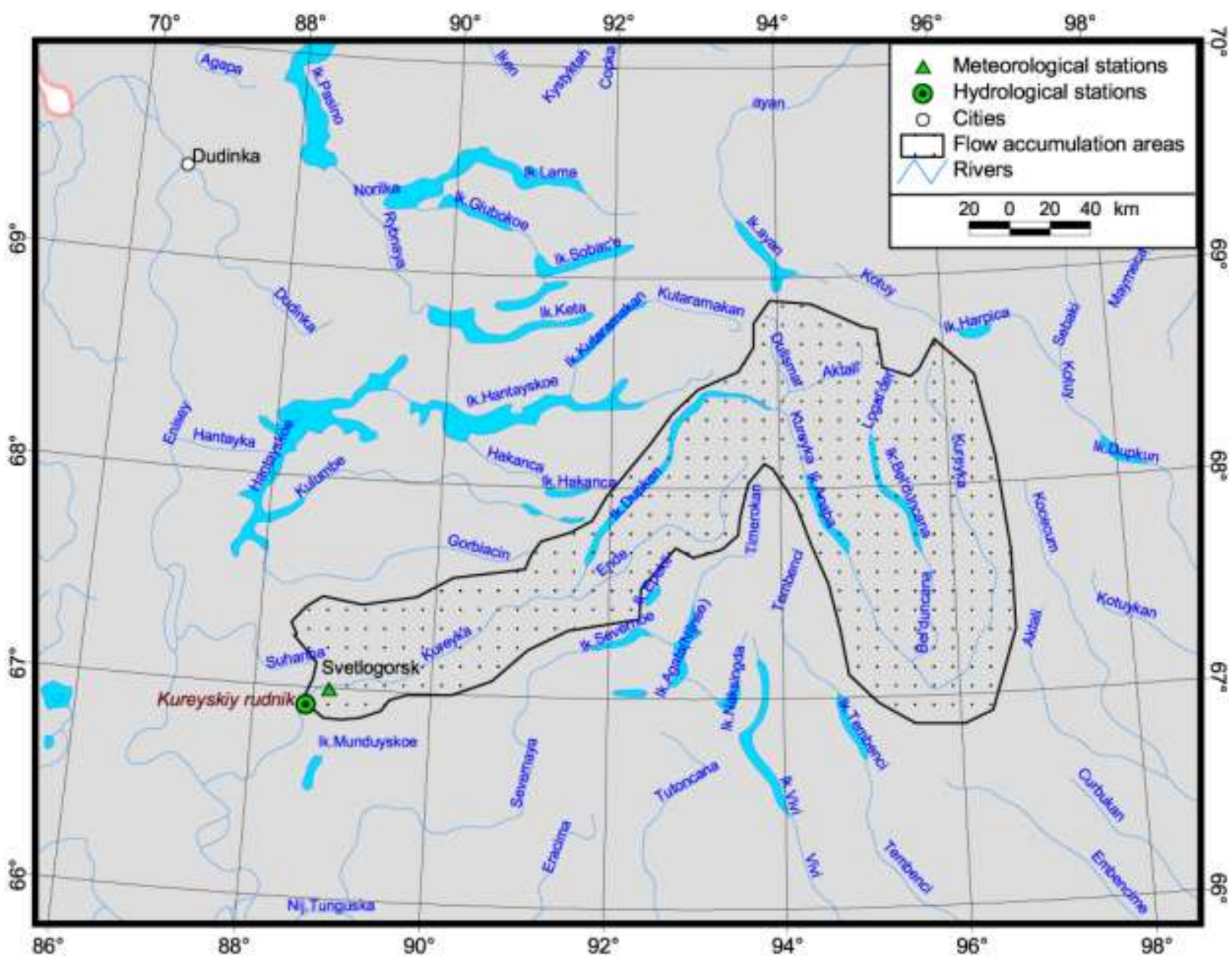

Figure 3 ) is located in a zone of northern taiga and forest-tundra, while the river Karabula drains a catchment in the southern 


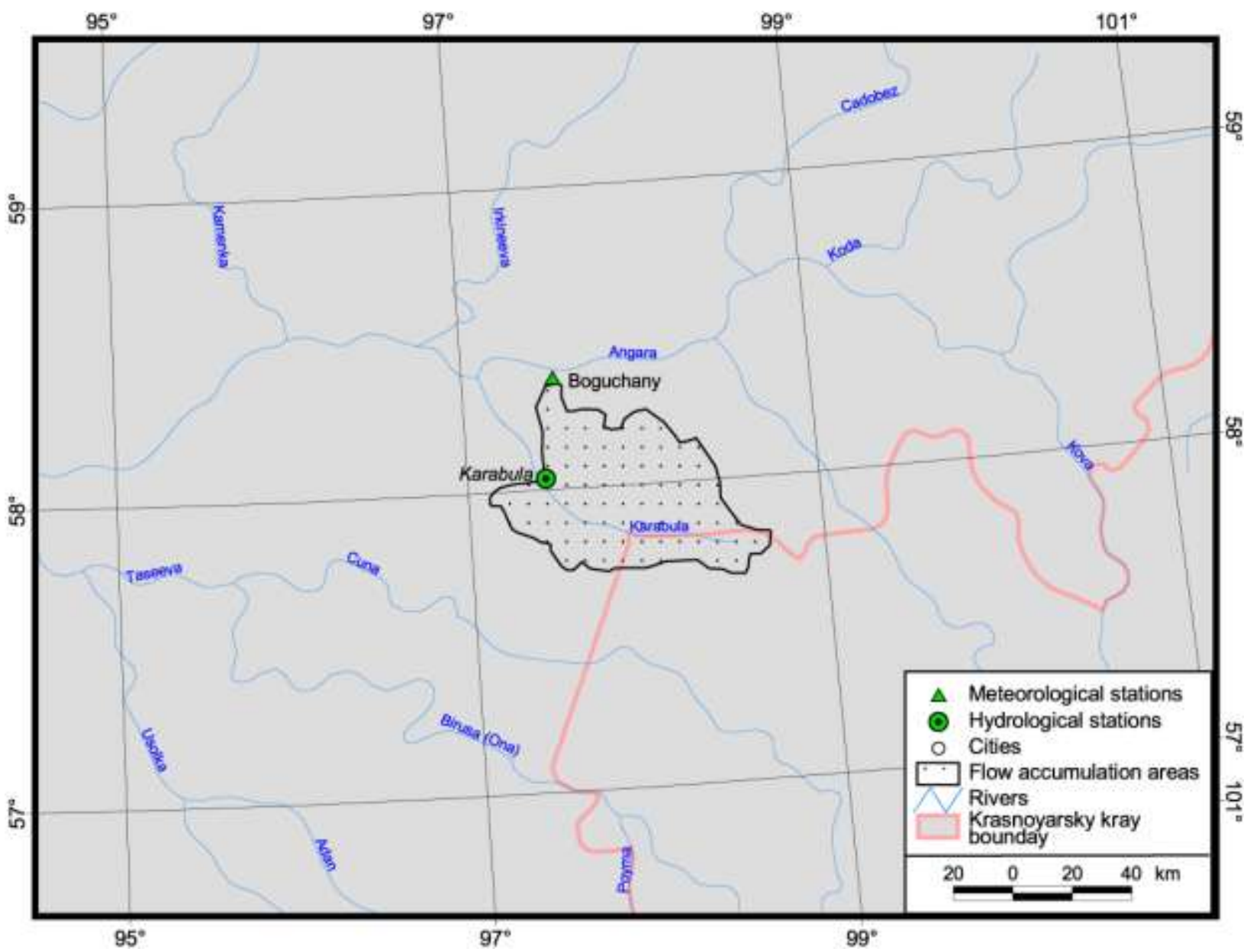

Figure 4). The basic water source of both rivers is snow. The Kureyka flows into the Yenisey river, so knowledge of its response to external stimulus is useful for the Arctic freshwater budget question outlined above. The Karabula drains an area of land that has experienced a dramatic land-cover change, with a decrease in overall forest area and a relative increase in deciduous trees.

Erba 


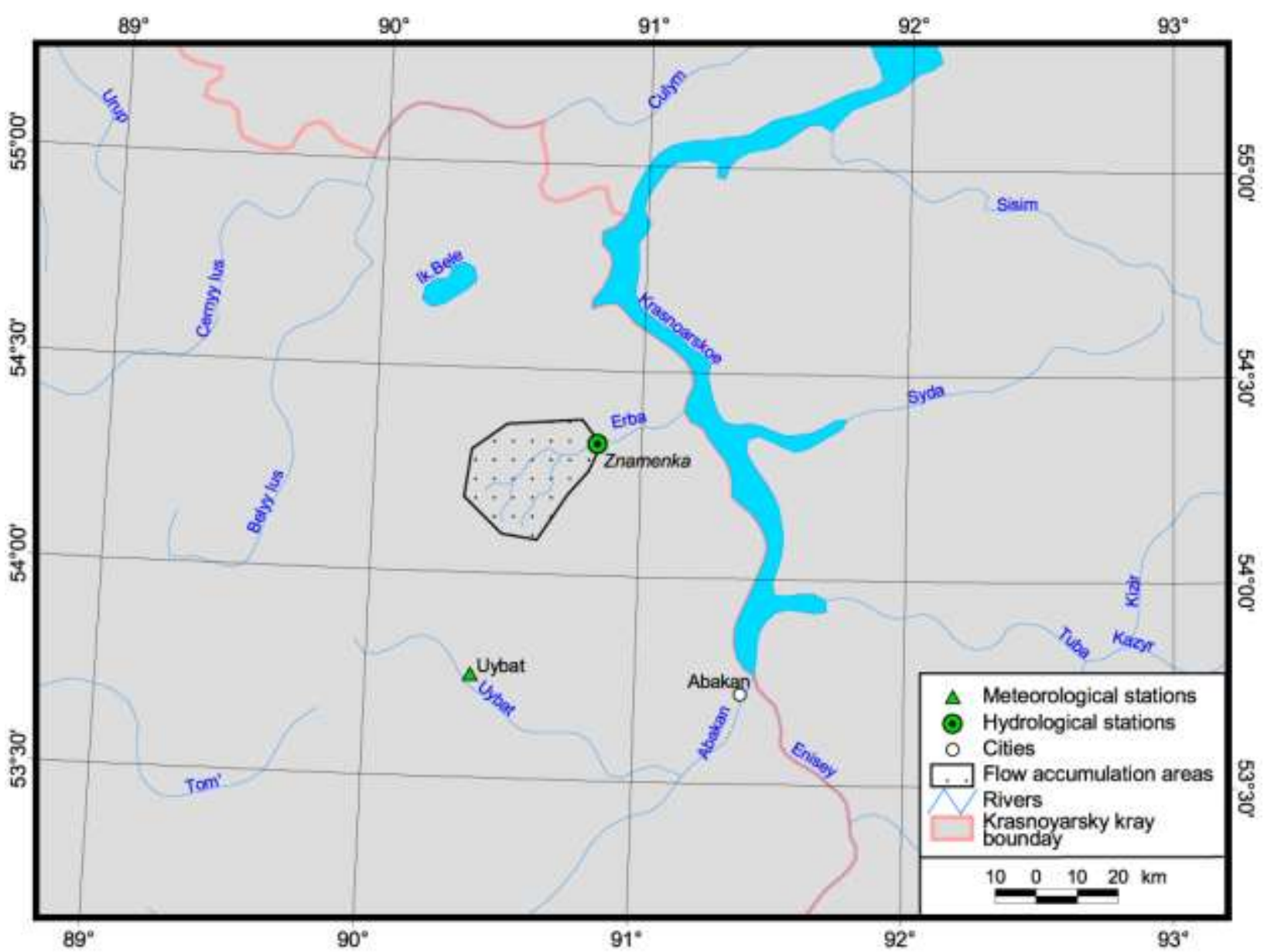

Figure 5) draws its water from forest-steppe ecosystems in a territory subject to intense agricultural use, with a water source of mainly rain. Impacts of land cover change in both these rivers will be of interest.

This paper adds to the collective understanding of the rivers in Northern Eurasia. It uses data to explore the response of the river flow to the climate and, unusually, it tests the idea that if the river flow is dependent on time as an explanatory variable, this could indicate an impact of land cover change.

\section{Material and methods}

\section{Hydrological and meteorological data}

Six rivers were chosen to compare the factors influencing river runoff formation in Europe and Siberia, and to interpret emerging climatic and geographic patterns. The catchments of three rivers are located in Western Europe, and three in different natural zones of Siberia. The European rivers investigated are Maas, Rhine and Odra, and the Siberian rivers the Kureyka, Karabula and Erba. Some characteristics of these rivers and hydrological stations from which observational data were used are described in Table 1. The Rhine is formed in the Alps in southeastern Switzerland, and then runs north through western Germany and the Netherlands into the 
North Sea. The Odra (German "Oder") originates in the mountains of the eastern Czech Republic, then flows west and north through Poland, forming the border to Germany, and eventually flows into the Baltic Sea. The river Maas (Flemish "Maes", French "Meuse") originates at Pouilly on the Langres Plateau in France and flows northward through Belgium and the Netherlands into the North Sea.

The catchment of the Kureyka is located in an area of northern taiga and forest-tundra. The river Karabula drains a catchment in the southern taiga, while the Erba draws its water from forest-steppe ecosystems. Since 1987 the river runoff of the Kureyka has been monitored directly at the Kureyka Hydroelectric power station, the dam of which is near to a former hydrological station. The Kureyka catchment is dominated by mountain tundra, though in river valleys larch forest prevails. Along the Kureyka and its tributaries are cascades of flowing lakes. The basic water source of the river comes from thawed snow. The river Karabula is fed from different sources, though mainly from melting snow. Until 1965 the logging in the forests in the Karabula catchment was low. Since 1965, however, there has been an intensification of logging, which has resulted in a reduction of the overall percentage of forest land, and to a relative increase in the area of deciduous woodland, which forms an early stage of vegetation succession after forest disturbances in Siberia. The catchment of the river Erba is subject to intense agricultural use. The river gets its water from a mixture of sources, though mainly from rain. For each of the rivers the dependence of annual runoff on a number of hydro-climatic parameters was analyzed with mixed regression models.

Hydro-meteorological data for the European rivers were received from the Royal Dutch Meteorological Institute KNMI, and are based on the Global River Discharge Database (RivDIS v1.1; Vörösmarty et al. 1998).

\section{Statistical models}

The runoff data were analysed by multiple regression analysis. For the European rivers annual runoff and precipitation is based on the calendar year, while for the Siberian rivers they refer to the hydrological year, which ranges from 1 October of the previous year till 30 September of the current year. The latter is based on the onset of freezing conditions, which in large parts of Siberia occurs in October. A knowledge-based approach was used to select the explanatory variables, based on the extensive experience of the Sukachev Institute of Forest, Krasnoyarsk of simulating Siberian rivers. In the selection of explanatory variables we allowed for synergetic effects on runoff. An analysis of the residuals from intermediate models was used to improve the models. In case of a correlation of the residuals with a further explanatory variable, for example with the runoff in the previous year or with time, these factors were 
included in the model and the next iteration of calculations was carried out. The main criterion to quantify model performance was the multiple coefficient of determination, which indicates the proportion of variation in the river runoff data that can be explained by all the factors included in the model. If $r^{2}<0.5$ then additional factors were investigated, considering synergistic effects between the explanatory variables, and a better model was constructed. This method will be illustrated in the Results Section for the river Erba.

\section{Results}

Simple scatterplots of annual precipitation data and river runoff are shown in 

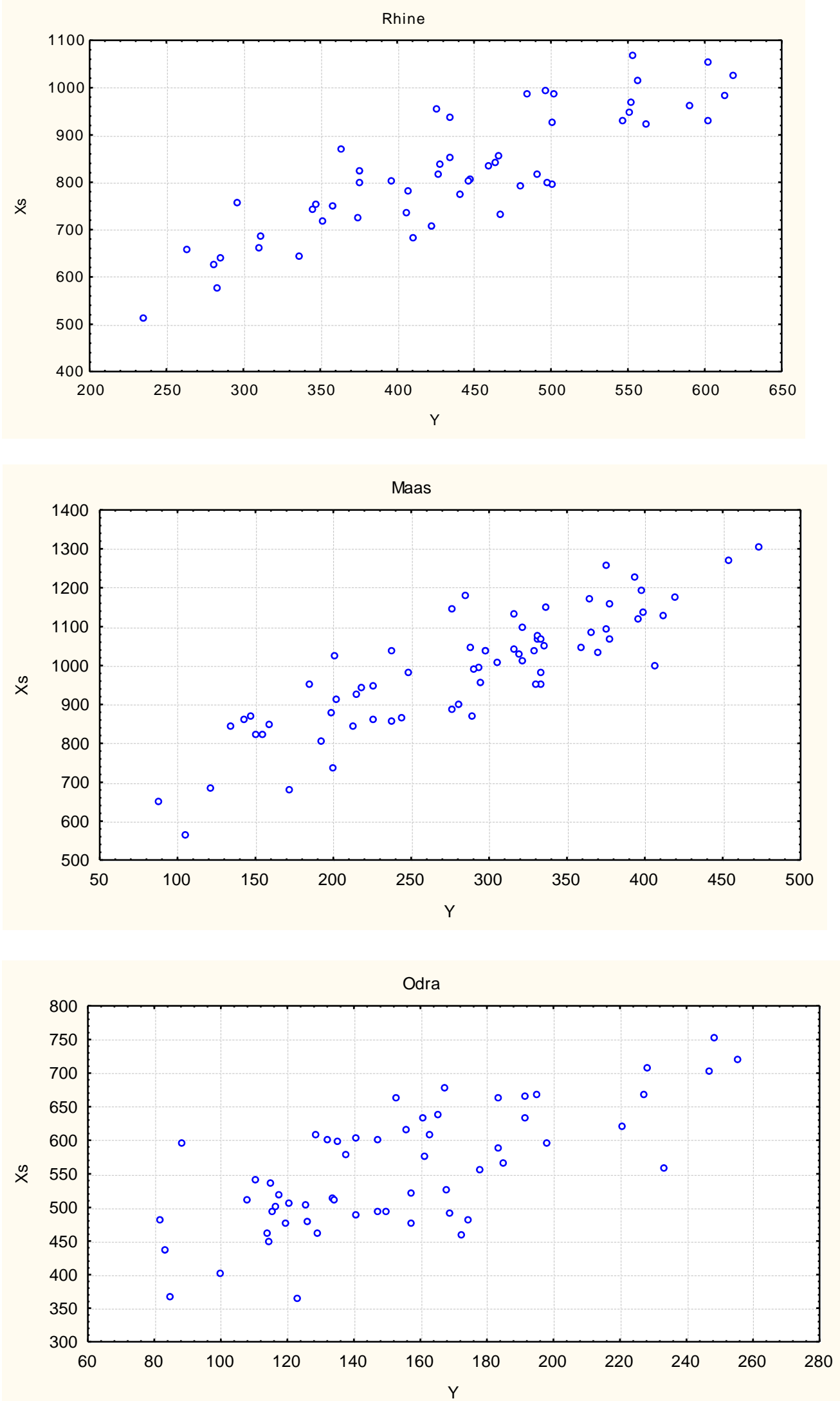

Figure 6 for the European rivers and in 

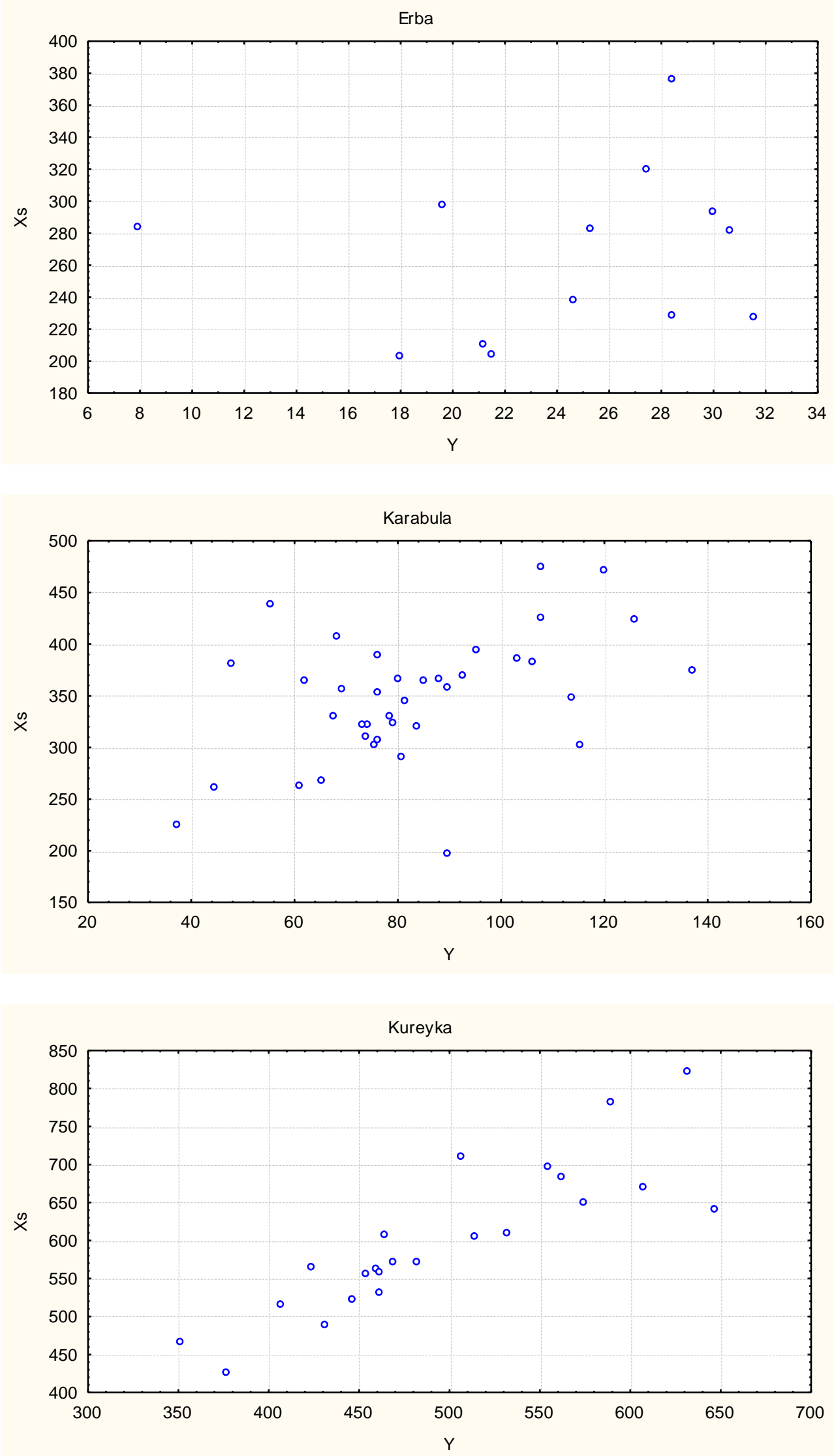

Figure 7 for the Siberian rivers. An overview of the fitted models of river runoff variability is given in Table 2. For the Maas, observations of hydro-meteorological data were available for 68 years: 1916-1949, 1957-1990. The fitted regression model is given in Table 2. The annual runoff of the Maas increases with precipitation and reduces with higher August 
temperatures. Positive autocorrelation of the runoff with the previous year is present. For the Rhine, hydro-meteorological data for 53 years were available: 1938-1940, 1942-1982, 1984, 1986-1988, 1993, 1996-1999. The annual runoff of the Rhine is high in years of high overall precipitation and is reduced in years with higher air temperatures in July and August. As for the Maas, the time series shows correlation with the previous year's runoff. For the river Odra, hydro-meteorological data for 58 years were available: 1921-1944, 1946-1970, 1973-1976, 1978, 1980-1981, 1984-1985. As for the Rhine, the annual runoff of the Odra increases with increasing precipitation and is reduced with higher air temperatures in July and August. As for the Rhine and the Maas, autocorrelation with the runoff of the previous year is also present.

For the Siberian river, Kureyka, observations of hydro-meteorological data for 23 years were available from 1976 to 1998. The annual runoff of the river Kureyka increases with an increasing amount of precipitation (including rain and snow) and the runoff in the previous year. A higher September air temperature in combination with higher precipitation for the same period has a positive effect on runoff. For the river Karabula hydro-meteorological data for 38 years were used (1951-1998). The model in Table 2 shows that annual runoff of the Karabula increases with higher precipitation (including snow and rain). A decrease of the runoff is observed with increasing air temperatures in May and July, whereas an increase of September air temperatures is accompanied by an increase in runoff. For the river Erba observations include the hydrometeorological data for 13 years from 1952 to 1963 and 1965. The annual runoff of the river Erba is reduced with increasing air temperatures from May till July, while the other analyzed meteorological parameters do not show a statistically significant relationship.

The analysis of the models presented in Table 2 reveal certain geographic and climatic features of the formation of annual runoff volume of the six studied rivers. It has to be noted that the volume of annual runoff is mostly determined by hydro-climatological parameters, and tends to be highest under conditions of high precipitation and low summer air temperature, i.e. conditions which resemble an oceanic climate. The more continental the climate, with a trend from Western to Eastern Eurasia and from the North to the South, the less likely it is that meteorological parameters show a statistically significant relationship to river runoff. While the models for Rhine, Maas and Kureyka explain $81 \%-83 \%$ of runoff variability, the models for Odra and Karabula only explain $65 \%$ and $47 \%$, and for Erba only $28 \%$. This suggests that for the latter three rivers other factors than the meteorological parameters described above are influencing runoff. Under their more continental climate conditions the land surface is likely to play a more important role in determining catchment hydrological processes. This could explain the observed decrease in the $r^{2}$ values, on the assumption that the variation in catchment size (Table 1) does not introduce a bias. 
On the other hand, the mechanisms of annual runoff formation in the Western Eurasian continent are well understood. The structure of the regression models is universally valid for all three studied rivers of this region - Maas, Rhine and Odra. The precipitation, prior hydrological conditions in the catchments, expressed through the runoff volume from the previous year, and summer air temperatures can be used as predictors in all models.

Annual runoff of the Kureyka and Karabula increases with increasing air temperatures at the end of the summer period (Table 2). These rivers are situated in the Siberian ecological zones of the forest-tundra transition belt and the taiga forest where permafrost conditions prevail. Permafrost moisture from periodical thawing of the top soil horizon is likely to be the cause for this phenomenon. The volume of river runoff in the southern taiga (Karabula) depends on a ratio of precipitation and evaporation. With increasing atmospheric precipitation the runoff increases, and with increasing July temperatures the runoff is reduced. In the forest-steppe conditions of insufficient precipitation and a high air humidity deficit, the runoff is not dependent on the total precipitation. In fact, the rate of precipitation contributing to the formation of river runoff in these conditions depends less on mean rainfall that on its temporal distribution and on soil and vegetation conditions. For instance, if precipitation falls under conditions of low temperatures and high soil moisture, a high fraction contributes to the formation of runoff. Whereas under conditions of a soil moisture deficit and air humidity deficit, some proportion of the precipitation fills up the storage capacity of the soil, is evaporated, and only a small fraction contributes to runoff formation, even for strong rain events.

The second part of the analysis investigates the use of time as an additional predictor in the hydrological regression models. The annual runoff volume of the two rivers Maas and Erba is statistically related to time as a regressor. An analysis of the residuals showed that for the Maas, a change in runoff is detectable over time only between 1916 and 1949, and for Erba between 1957 and 1965. The regression model for Maas, which now includes time as an indicator for changing non-meteorological conditions (e.g. land use) takes the form:

$$
\begin{aligned}
& \mathrm{Y}=-357.6+0.46 \cdot \mathrm{X}_{\mathrm{s}}+108.7 \cdot \ln \mathrm{X}_{\mathrm{s}} \cdot \ln \mathrm{Y}_{\mathrm{p}} / \mathrm{t}_{\mathrm{t}}-1.35 \cdot \mathrm{T} \\
& \mathrm{r}^{2}=0.84 \mathrm{G}=37.2 \mathrm{~F}=111.2
\end{aligned}
$$

Where: $\mathrm{T}=$ time (year in 20th century in an interval from 16 up to 49; after $1949 \mathrm{~T}=49$ const.); the other symbols as in Table 2.

For the river Erba this results in: 
$\mathrm{Y}=163.5-2.0 \cdot \mathrm{T}-0.44\left(\mathrm{t}_{5}+\mathrm{t}_{6}+\mathrm{t}_{7}\right)$

$$
\mathrm{r}^{2}=0.93 \mathrm{G}=2.1 \quad \mathrm{~F}=62.7
$$

Where: $\mathrm{T}=$ time (year in 20th century in an interval from 52 up to 65 ; before $1957 \mathrm{~T}=57$ const.); with symbols as in the legend to Table 2.

Concerning the physical explanation of the structure of the developed regression model equations we want to describe the way in which the regression model in Eq. 1 was derived for the river Maas as an example. The analysis of the structure of the previous regression equation allows to detect positive synergetic effects of the precipitation and runoff of the previous year on the runoff of the current year (sign ' + '). At the same time the increase of air temperatures in August is statistically significantly connected to a decrease in runoff. It confirms by that "t8" is best included as a denominator because an increase in "t8" will be accompanied by decreasing runoff in Eq. 1.

Regarding Eq. 2 for the Erba river, under dry conditions the fraction of the precipitation expended on formation of river runoff depends not so much on the precipitation amount but on their time distribution and condition of the top soil. If the precipitation falls during low air temperatures and high soil wetness, a significant part is used in river runoff formation. Under lack of soil moisture and warm air, the precipitation replenishes the soil water, is partly evaporated, and to a smaller extent contributes to runoff formation. This is true even for strong rainfall events. This is the main cause that no statistically significant relationof the Erba river runoff with precipitation can be detected 

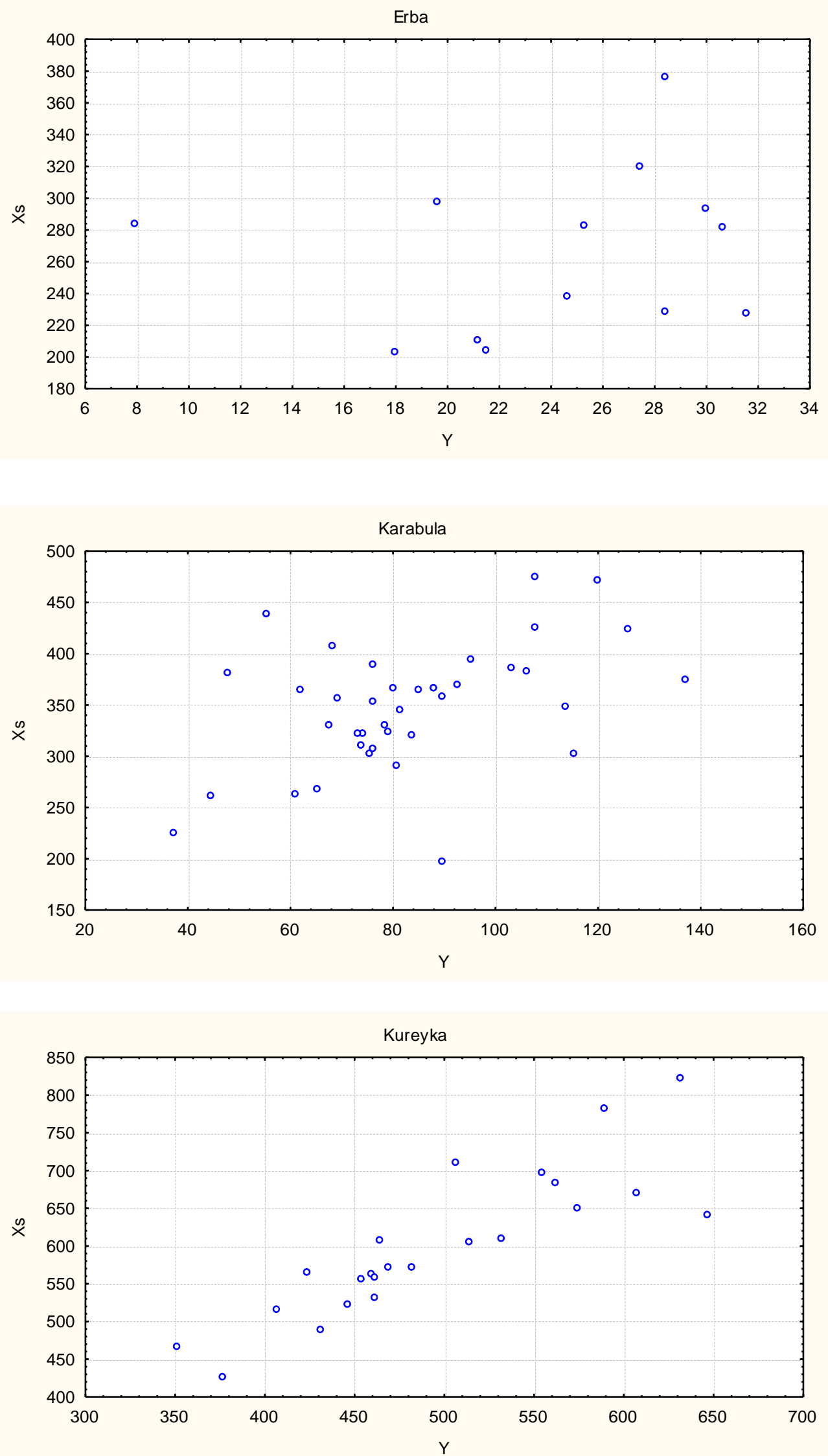

Figure 7 top).

That the factor of time is statistically significantly connected to changes in runoff of the rivers Maas and Erba can be interpreted as an indicator of land use change impacts on the 
catchments. Given the fact that we have accounted for climatic parameters, land cover and land use change is the single unaccounted factor that most plausibly explains changes in the hydrological regimes in the catchments. The time from 1957 to 1965 coincides with the beginning of land use intensification in the Erba catchment in the southern parts of the Krasnoyarsk Kray region. The residuals analysis of the Erba models with and without time as a

A

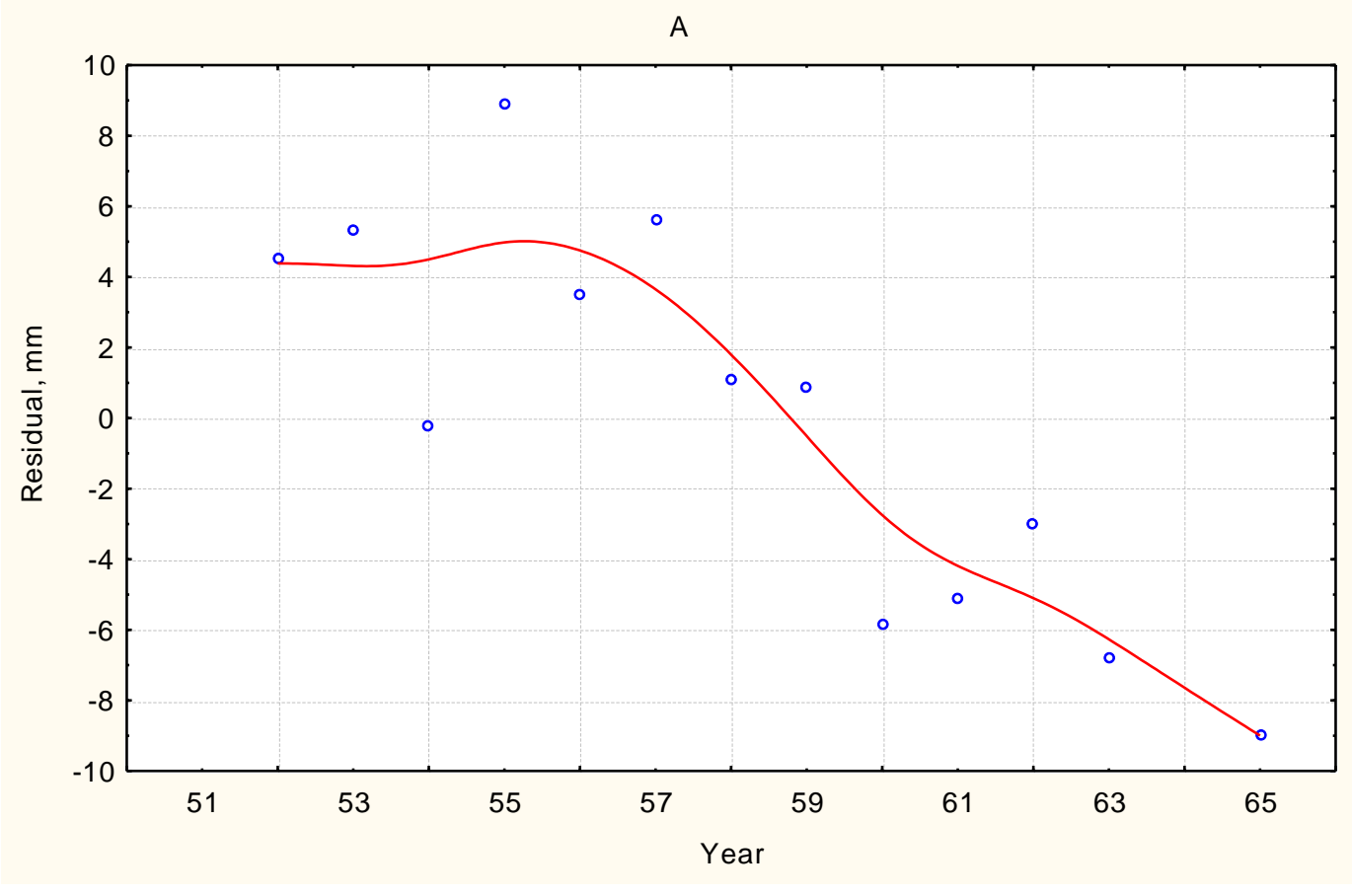

regressor in

B

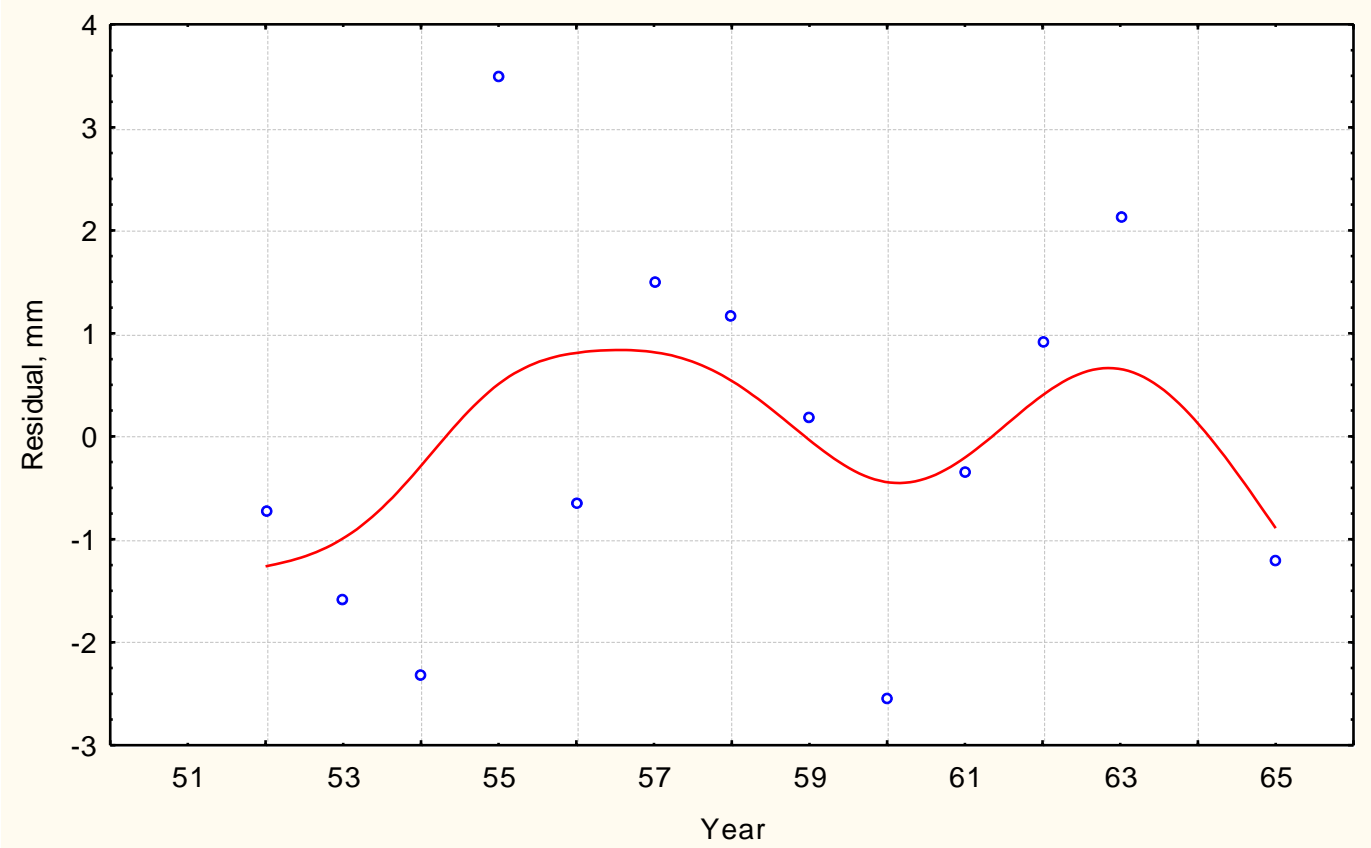


Figure 10 supports this interpretation. In the case when the time factor was non used in the model the residuals after 57 years show a decreasing trend

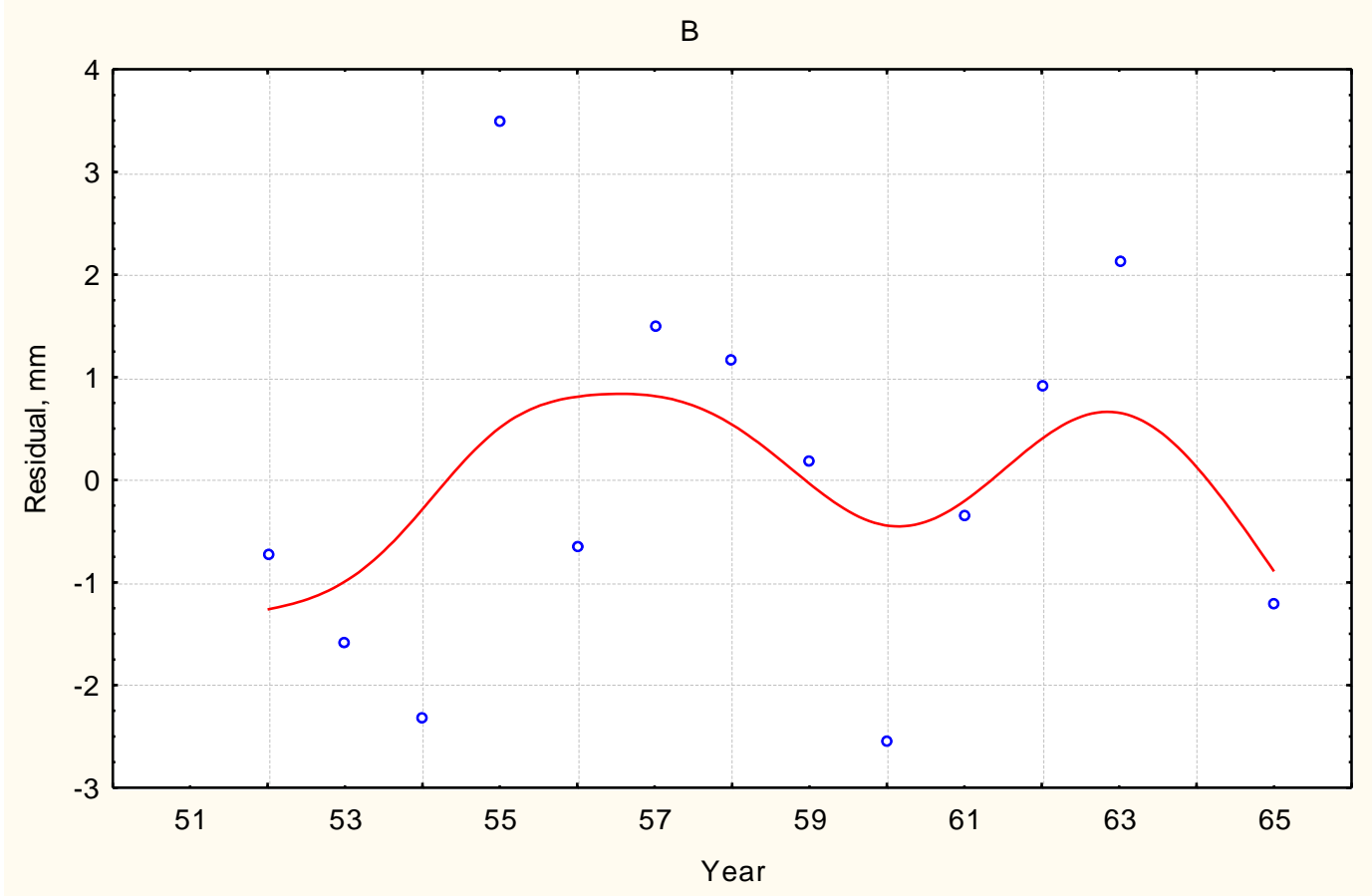


Figure 10a). When the time factor was used in the model the residuals do not show any

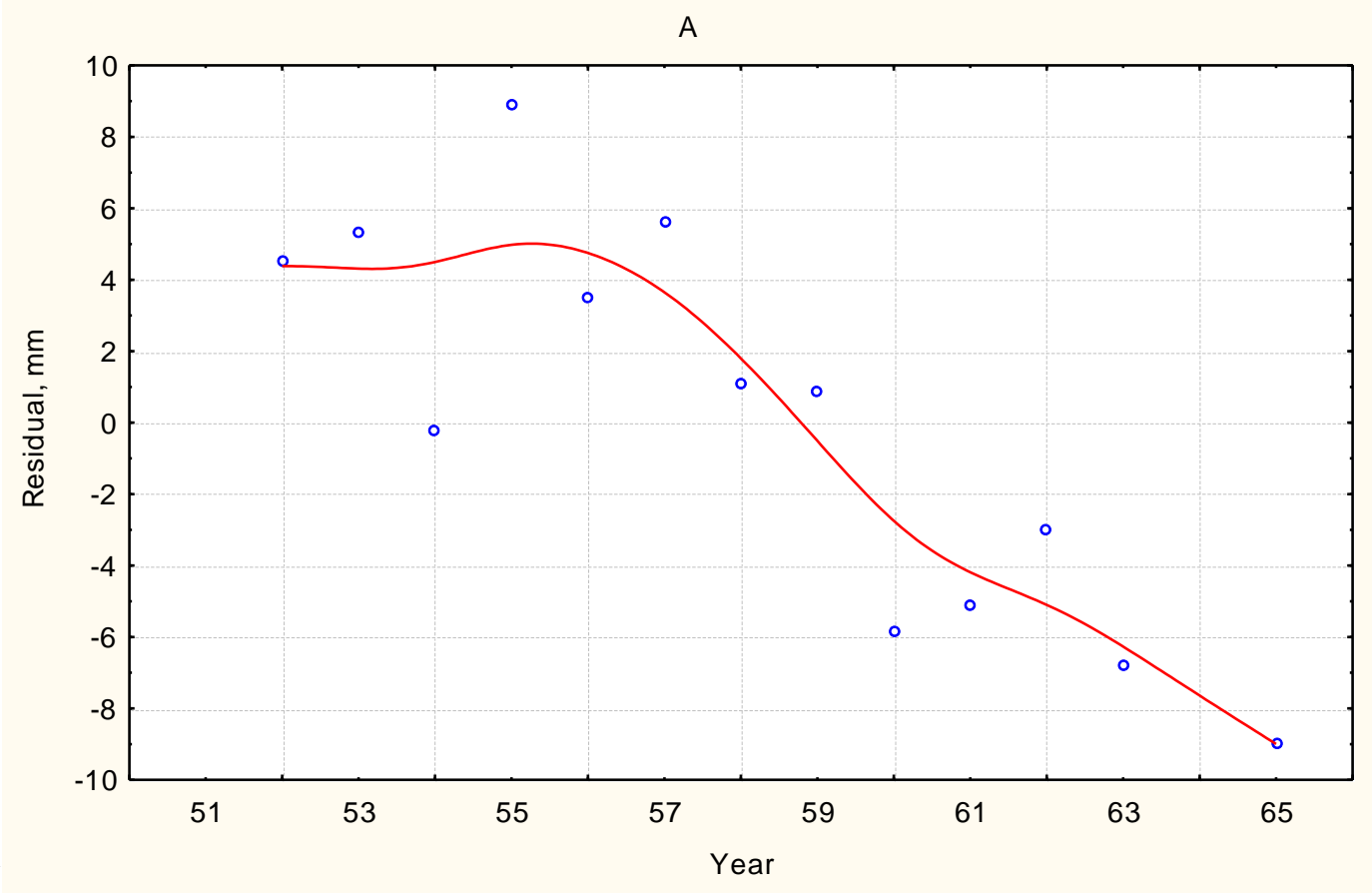

trend (

B

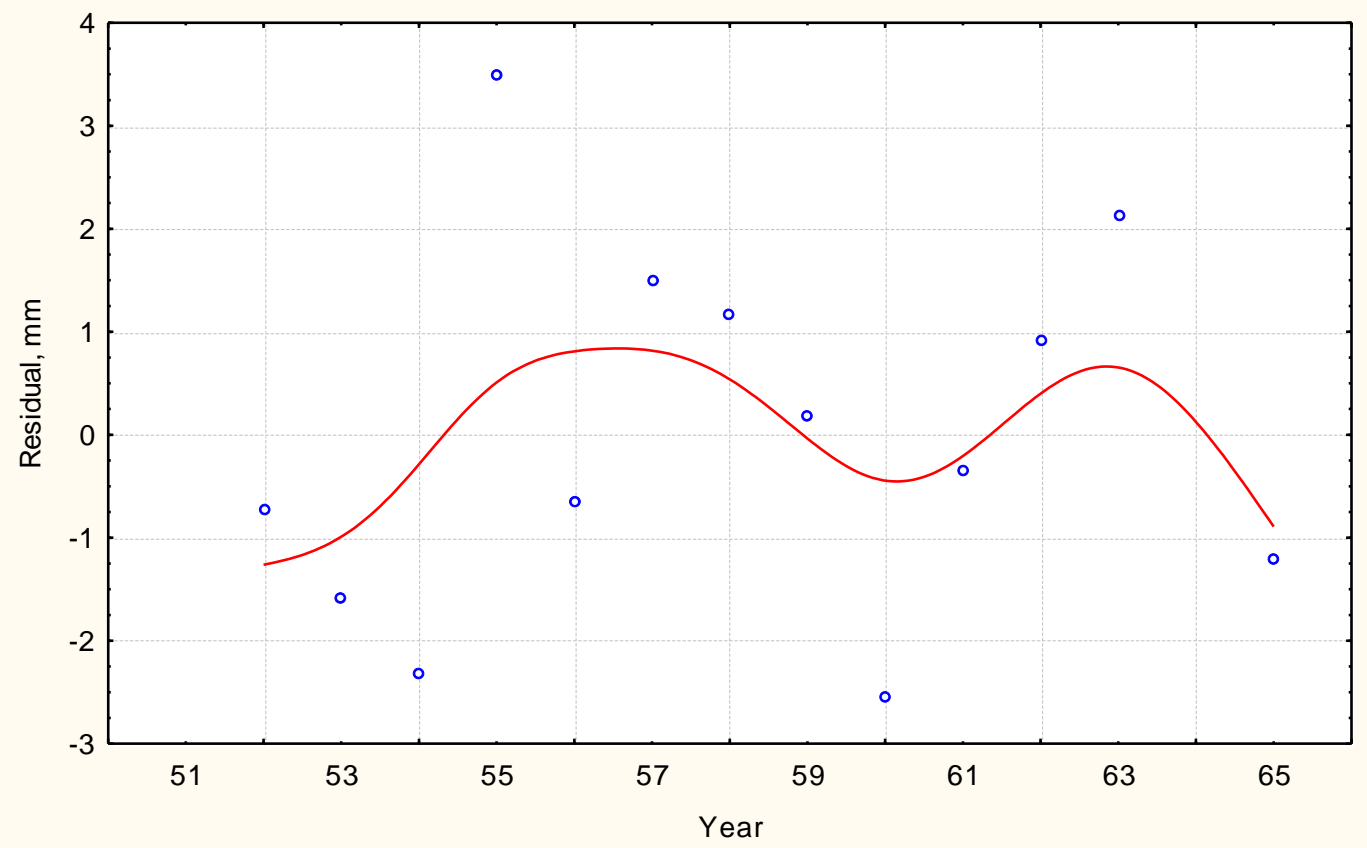

Figure 10b). Therefore we conclude that the major factors determining the formation of the Erba river runoff are summer air temperatures and time.

The results above suggest that land use changes explaining changes in runoff also took place between 1916 and 1949 in the Maas catchment. Eq. (2) shows that with the beginning of intensive land use in the catchment of the Erba the water balance structure has changed. The impact of land use manifests itself in a redistribution of the water supply through changes in 
evaporation and a reduction of river runoff. This phenomenon is independent of meteorological conditions in the catchment and can be quantified as an annual decrease of river runoff of $2 \mathrm{~mm}$. The quite drastic change of annual river runoff of the Erba is apparent when comparing
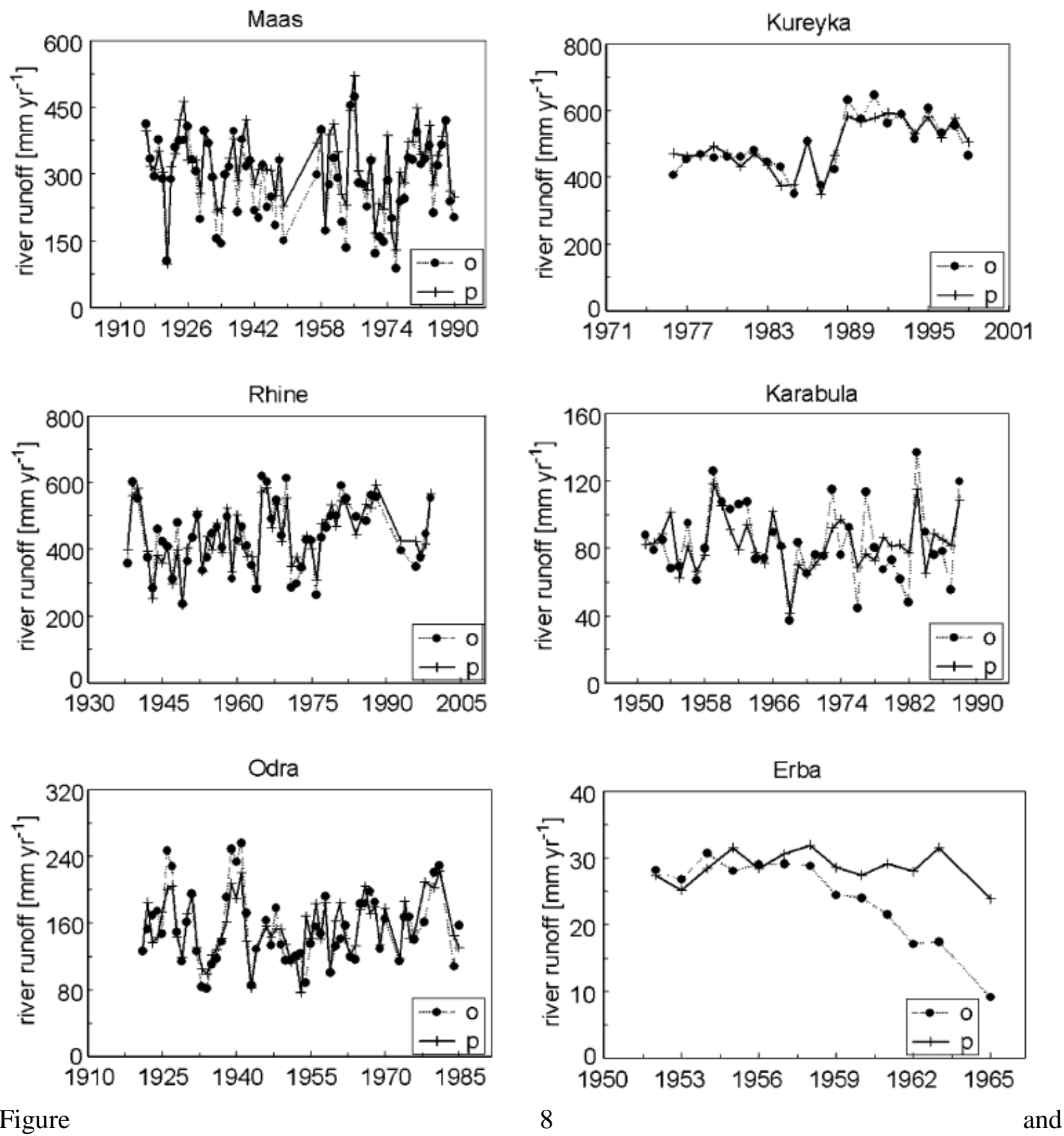

Figure
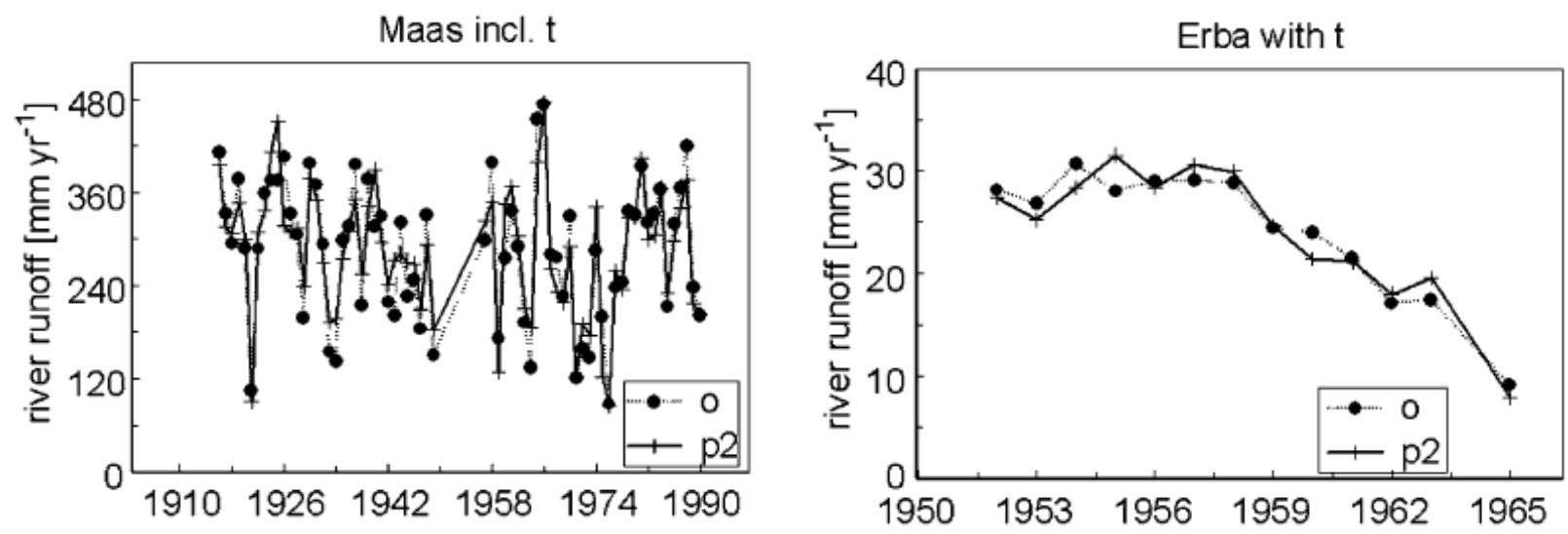
Figure 9. The Erba model predictions in the absence of disturbance due to land use are given in
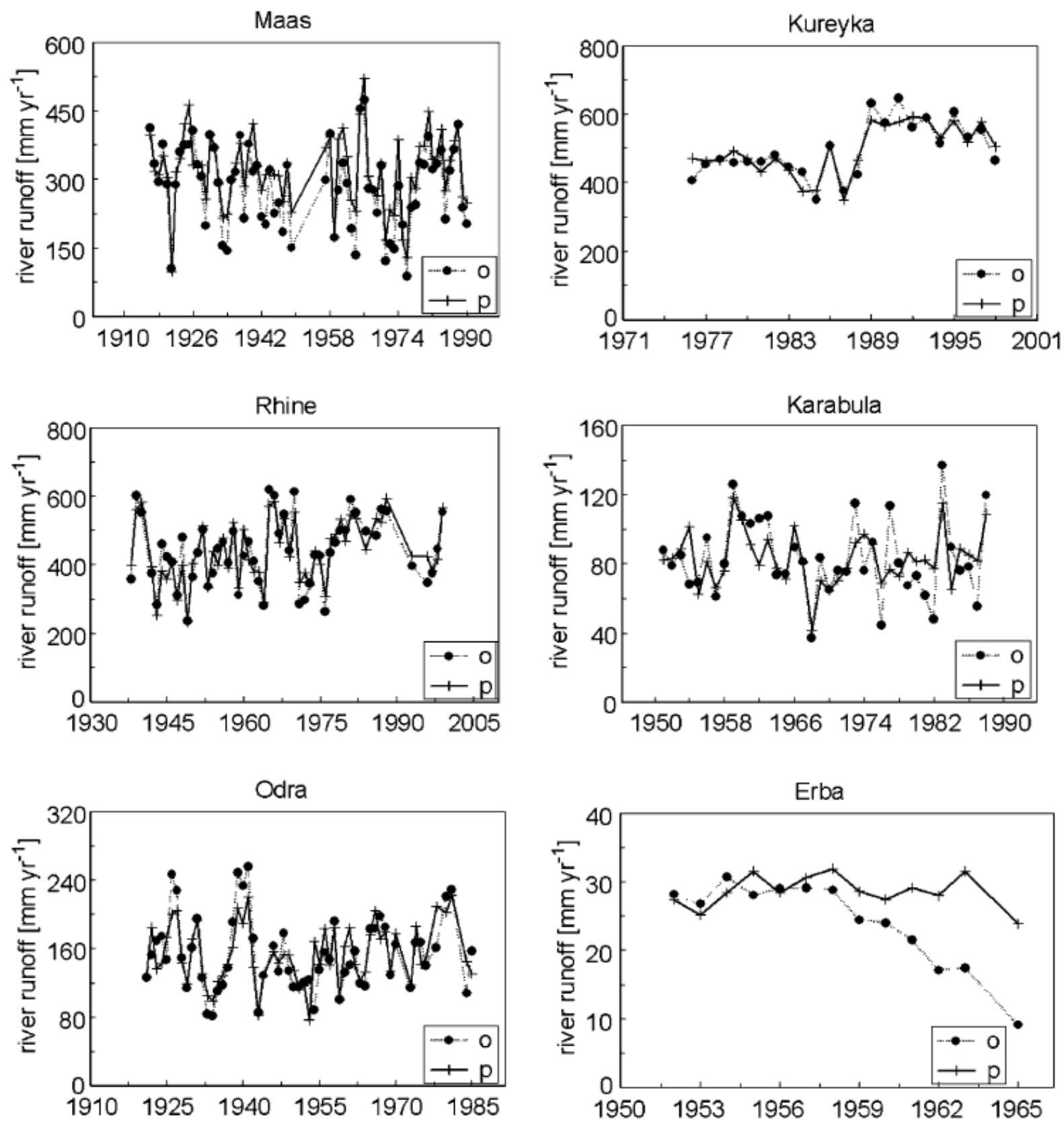

Figure 8 . The observed runoff declines rapidly after the intensification in land use sets in. The drainage basin of the Erba is located in the Minusinsk hollow, which has edaphic and climatic conditions that are favourable for crop growing and livestock farming. In Krasnoyarsk Kray from the beginning of the 20th century the area under agricultural land use has been steadily increasing, from 0.6 million hectares in 1913 to 2 million hectares in 1940 and about 3.2 million hectares in 1958 (Bandman, 1962). In some regions of Minusinsk hollow, the area of agricultural crops increased 3.5 times between 1954 and 1961 (Golovkin, 1962).

Before 1949, the Maas catchment experienced a reduction in the annual river runoff of $1.35 \mathrm{~mm} \mathrm{yr}^{-1}$. It is not possible to explain this decrease from the climatic conditions. We suggest that this decrease of river runoff was caused by land use change in the Maas catchment. After 1949, the change of the Maas runoff is statistically linked only to the meteorological 
characteristics and does not depend on the factor of time. This can be interpreted as a stabilization of land use taking place and a new equilibrium of the hydro-climatic processes corresponding to the new land-use. From the data, there seem to be no tendencies to re-establish the pre-1949 levels of runoff rate.

\section{Discussion}

Concerning the climatic aspects of runoff formation, it is clear that the influence of the hydrological conditions of the previous year is a prominent feature of all three studied WestEuropean rivers and the Kureyka river. Under conditions of permafrost and a cold, humid climate (Kureyka) a certain part of the precipitation in the catchment is frozen and stored as permafrost, snow or ice. This water pool is released in the following year under thawing conditions, contributing to runoff formation with a time lag of one year. For the West-European rivers, this time-lag effect can be caused by a high soil moisture capacity, which under an Atlantic climate (moist and warm) provides interannual correlations of river flow. Thus the previous precipitation in a catchment can influence the runoff of the current year.

Under conditions of insufficient precipitation this time-lag effect disappears, and no autocorrelation with the previous year is observed. The analysis of the river runoff formation in the southern taiga and forest-steppe sites shows these characteristics. Zavilevskiy et al. (2000) used stable radio-isotopes to study the hydrology of Siberian river basins. They found that precipitation falling in a river basin can remain in the basin from several months till 3 years before it will be carried out of the basin in the river runoff (Zavilevskiy et al., 2000). The annual river runoff volume in the southern taiga is influenced first and foremost by the ratio of precipitation and evaporation. With increased atmospheric precipitation, the drainage flows increase. For the Karabula no statistically significant connections of annual runoff with the previous year were found. At the same time higher air temperatures at the end of spring and in the middle of summer cause a reduction of the annual runoff volume. This finding confirms results by Tchebotaryov (1962) studying the dependence of evaporation on air temperature. A reduction of runoff is also connected with an increase in air humidity deficit which, together with soil moisture, determines evaporation (Bagrov, 1953). In the catchment of the Karabula river, a statistically significant increase in runoff takes place during high September air temperatures, which are thought to be connected with water mobilization from melting permafrost.

Ye et al. (2003) showed for the Lena sub-catchments that reservoir regulation can influence the runoff patterns significantly. No artificial dam is present on the main arms of the Erba, Karabula and Kureyka. There are two lakes on the main stream of the Kureyka - Djupkun 
and Anuma. Djupkun is now impounded by the Kureyka hydroelectric power station reservoir and is being used as an integrated water reservoir. Among the lakes contributing indirectly to the Kureyka the largest lake is Belduchana on the river Belduchana.

The climatology concept continues to be the prevailing paradigm in some branches of hydrology as drainage dynamics are closely connected to meteorological conditions of precipitation and evaporation. However, as is well known in process hydrology, river runoff formation is caused by a complex combination of factors describing the river catchment, including soil and geological conditions, vegetation, permafrost, topography, soil wetness, presence of lakes, density of the drainage network, size and form of the catchment. Long-term experience of complex hydrological research in various geographical and climatic conditions stimulated the development of a systems concept for simulating the formation of drainage. As early as in V.V. Dokuchayev's work (1892) the role of the soil as a hydrological factor has been recognised. It is known that anthropogenic land cover change can lead to hydrological changes through the removal of natural forest and resulting increased evapotranspiration. Such changes are first and foremost consequences of agricultural activity. A study by De Roo et al. (2001) of the flooding regimes of the Maas and Odra using the model LISFLOOD found some modelbased evidence of land use and vegetation change effects on the water balance in those catchments. To obtain reliable data on the dynamics, character and scale of agricultural land use can be very difficult for some parts of the world. Nevertheless it is obvious that hydrological phenomena are connected to cumulative effects of land use and agricultural intensification. These factors are changing over time. After explaining variability in runoff caused by meteorological parameters, we make the assumption that time can be used as an indicator variable for land use change, the second most important influence on river runoff.

The analysis of geographic and climatic patterns of Northern Eurasian river runoff formation leads to the following conclusions:

- The role of precipitation and correlation with previous year runoff as factors in the formation of river runoff is stronger under oceanic climate conditions, increasing from the central regions of Northern Eurasia towards the Arctic Ocean in the North and the Atlantic in the West. At the same time the role of summer temperatures is reduced.

- The formation of Northern Eurasian river runoff appears to be influenced by periodically thawing top horizons of permafrost soil.

- Anthropogenic influence on the character of a drainage basin is suggested as the reason for the observed influence of time as a regressor in the models for Maas and Erba. Agricultural activity and land use is an important factor in the runoff formation and can result in changes of the water balance of large regions with a resulting redistribution of 
water supply through changes in evaporation and a reduction of river runoff. Under intensive agricultural land use, anthropogenic pressures can become a major factor determining the conditions of runoff formation. Land use acts as a form of terrestrial ecosystem disturbance.

- By means of an analysis of annual runoff formation it is possible to detect the onset of anthropogenic disturbances and to estimate their impact. Thus a change of the runoff formation can be used as an environmental indicator for sustainable land use. The river runoff integrates changes of land surface/atmosphere exchange processes in the entire catchment. These processes can be drastically altered by human land use change.

\section{References}

Bagrov N.A. About mean perennial vaporization from a surface of the land. Russian Journal «Meteorology and hydrology » N10, 1953. P. 23-27. (In Russian)

Bandman M.K. The Industrial specialization and the ways of integrated development of Krasnoyarsk Region economy// The Siberian geographic collection. 1962 N 1. P 54-68. (In Russian)

Berezovskaya, S., Yang, D. and Kane, D.L., 2004, Compatibility analysis of precipitation and runoff trends over the large Siberian watersheds. Geophysical research letters, vol 31, L21502.

Betts, R.A. 2000. Offset of the potential carbon sink from boreal forestation by decreases in surface albedo. Nature, 409. 187-190.

Callaghan, T.V., Bjorn, L.O., Chernov, Y., Chapin, T., Christensen, T.R., Huntley, B., Ims, R.A., Johansson, M., Jolly, D., Jonasson, S., Matveyeva, N., Panikov, N., Oechel, W., Shaver, G., Schaphoff, S. and Sitch, S. 2004. Effects of changes in climate on landscape and regional processes, and feedbacks to the climate system. Ambio, vol 33, no 7. 459-468.

Carmack, E., 2000. The Arctic Ocean's freshwater budget: sources, storage and export. The freshwater Budget of the Arctic Ocean, eds: Lewis, E.L., Jones, E.P., Lemke, P., Prowse, T.D. and Wadhams, P. Kluwer Academic Publishers. P 91-126

De Roo, A., Odijk, M., Schmuck, G., Koster, E., and Lucieer, A., 2001, Assessing the effects of land use changes on floods in the Meuse and Oder catchment, Physics and Chemistry of the Earth Part B-Hydrology Oceans and Atmosphere, 26, 593-599.

Dokuchaev V.V. Our steppes before and now. SPB, 1892. (In Russian)

Golovkin D.A. Agricultural regions of Minusinsk hollow // The Siberian geographic collection. 1962 N 1. P 77-84. (In Russian)

Grabs, W.E., Portman, F. and de Couet, T. 2000. Discharge observation networks in Arctic regions: comparison of the river runoff into the Arctic Ocean, its seasonality and variability. The freshwater Budget of the Arctic Ocean, eds: Lewis, E.L., Jones, E.P., Lemke, P., Prowse, T.D. and Wadhams, P. Kluwer Academic Publishers. P 249-268

Gustard, A. and Cole, G.A., 2002. FRIEND (Flow regimes from International Experimental and Network Data) - a global perspective 1998 - 2002. UNESCO International Hydrological Programme V. Edited by A. Gustard and G.A. Cole. ISBN 1903741033 pp132

Harding, R., Kuhry, P., Christensen, T.R., Sykes, M.T., Dankers, R. and van der Linden, 
S. 2002. Climate feedbacks at the tundra/taiga interface. Ambio. Vol 12, 47-55

Lammers, R.B., Shiklomanov, A.I., Vorosmarty, C.J., Fekete, B.M. and Peterson, B.J., 2001. Assessment of contemporary Arctic river runoff based on observational discharge records. J.G.R., 106, 3321 - 3334

McClelland, J.W., Holmes, R.M., Peterson, B.J. and Steiglitz, M., 2004. Increasing river discharge in the Eurasian Arctic: consideration of dams, permafrost thaw and fires as potential agents of change. Journal of geophysical research, 109. D18102.

Peterson, B.J., Holmes, R.M., McClelland, J.W., Vörösmarty, C.J., Lammers, R.B., Shiklomanov, A.I., Shiklomanov, I.A. and Rahmstorf, S., 2002, Increasing River Discharge to the Arctic Ocean. Science 298, 2171-2173.

Pfister, L., Kwadijk, J., Musy, A., Bronstert, A., and Hoffmann, L., 2004, Climate change, land use change and runoff prediction in the Rhine-Meuse basins, River Research and Applications, 20, 229-241.

Prowse, T.D. and Flegg, P.O., 2000. Arctic river flow : a review of contributing areas. The freshwater Budget of the Arctic Ocean, eds: Lewis, E.L., Jones, E.P., Lemke, P., Prowse, T.D. and Wadhams, P. Kluwer Academic Publishers. P 269-280

Rahmstorf, S., 1996. On the freshwater forcing and transport of the Atlantic thermohaline circulation. Climate Dynamics. 12, 799-811

Shiklomanov, I.A, Shiklomanov, A.I., Lammers, R.B., Peterson, B.J. and Vorosmarty, C.J., 2000. The dynamics of river flow to the Arctic Ocean. The freshwater Budget of the Arctic Ocean, eds: Lewis, E.L., Jones, E.P., Lemke, P., Prowse, T.D. and Wadhams, P. Kluwer Academic Publishers. P 281-296

Tchebotaryov N.P. The doctrine about a runoff. Publishing house of Moscow University, 1962, pp. 406. (In Russian)

Van der Ploeg, R. R. and Schweigert, P., 2001, Elbe river flood peaks and postwar agricultural land use in East Germany, Naturwissenschaften, 88, 522-525.

Viterbo, P. and Betts, A.K., 1999. Impact on the ECMWF forecasts of changes to the albedo of the boreal forests in the presence of snow. J. of Geophys. Res., 102, 28901-28909

Vörösmarty, C.J., B. Fekete, and B.A. Tucker. 1998. River Discharge Database, Version 1.1 (RivDIS v1.0 supplement). Available through the Institute for the Study of Earth, Oceans, and Space / University of New Hampshire, Durham NH (USA).

Yang, D. Kane, D.L., Hinzmann, L.D., Zhang, X., Zhang, T. and Ye, H., 2002. Siberian Lena River hydrological regime and recent change. Journal of geophysical research, vol 107, D23, 4694.

Yang, D., Ye, B. and Shikolomanov, A., 2004b. Discharge Characteristics and Changes over the Ob watershed in Siberia. Journal of Hydrometeorology, vol 5, 595-610

Yang, D., Ye, B., and Kane, D.L., 2004a. Streamflow changes over Siberian Yenisei River Basin. Journal of Hydrology, 296, 59-80.

Ye, B., D. Yang and D. Kane, 2003: Changes in Lena River streamflow hydrology: human impact versus natural variations, Water Resour. Res., 39 (7), pp. 1200-1224.

Zavilevskiy S.V., Marunich S.V. and Sokolov B.L. The mechanism of river runoff formation on small catchment basin of Valdai // Russian Journal Proceedings of the Academy of Sciences. Series Geographical. 2000 N 2. P 37-41. (In Russian) 
Tables

Table 1: Hydrological stations and characteristics of the studied rivers

\begin{tabular}{|l|l|l|l|l|l|l|}
\hline \multirow{2}{*}{ River } & \multirow{2}{*}{$\begin{array}{l}\text { Total } \\
\text { length } \\
{[\mathrm{km}]}\end{array}$} & Socation & Station & \multicolumn{2}{|l|}{ Geographical coordinates } & \begin{tabular}{l} 
Distance \\
from \\
mouth \\
\cline { 3 - 7 }
\end{tabular} \\
\cline { 3 - 7 } & $\begin{array}{l}\text { Latitude } \\
\text { degree }\end{array}$ & $\begin{array}{l}\text { Station } \\
\text { catchment } \\
\text { area }\left[\mathrm{km}^{2}\right]\end{array}$ \\
\hline Maas & 950 & Borgharen & 50.88 & 5.68 & 255 & 27900 \\
\hline Rhine & 1319 & Lobith & 51.88 & 6.12 & 90 & 160000 \\
\hline Odra & 912 & Gozdowice & 52.76 & 14.32 & 120 & 109729 \\
\hline Kureyka & 888 & Kureyskiy rudnik & 66.91 & 88.33 & 98 & 39900 \\
\hline Karabula & 212 & Karabula & 58.04 & 97.40 & 48 & 4190 \\
\hline Erba* & 89 & Znamenka & 54.37 & 90.75 & 34 & 859 \\
\hline
\end{tabular}

* - before the establishment of the Krasnoyarsk Hydroelectric power station water basin.

Table 2: Fitted regression models and model fit for the six Eurasian rivers. $Y=$ annual runoff $[\mathrm{mm}] ; Y_{p}=$ annual runoff of the previous year $[\mathrm{mm}] ; X_{a}=$ mean annual precipitation $[\mathrm{mm}] ; X_{s}=$ precipitation for the warm season [mm]; $X_{w}=$ precipitation for the cold season [mm]; $X_{i}=$ mean monthly precipitation in month $i$ $[\mathrm{mm}] ; t_{i}=$ monthly average air temperature in month $i ; S_{n}=$ snow water equivalent measured along a snow survey route; $\mathbf{r}^{2}$ - coefficient of determination; $\mathbf{G}$ - standard error of the model; $F$ - Fisher Statistic. Meteorological stations used for the Maas analysis were Chiny/Lacuisine, Xives, Stavelot, Maastricht/Z. Limburg (solely for $t_{8}$ ) and Leopoldsburg/Koersel; for the Rhine: Strasbourg/Entzheim, Nancy/Essey, Zurich/Town and Trier-Petris $B$ only for $t_{7}, t_{8}$; for the Odra: Praha/Ruzyne, Wroclaw $\left(t_{7}\right.$, $t_{8}$ solely based on Wroclaw), Potsdam; for the Kureyka: Svetlogorsk meteorological station and snow survey route; for the Karabula: meteorological station Boguchany;and for the Erba: Uybat.

\begin{tabular}{|l|l|l|}
\hline river & model & model fit \\
\hline Maas & $\mathrm{Y}=-423.4+0.46 \cdot \mathrm{X}_{\mathrm{a}}+112.9 \cdot \ln \mathrm{X}_{\mathrm{a}} \cdot \ln \mathrm{Y}_{\mathrm{p}} / \mathrm{t}_{8}$ & $\mathrm{r}^{2}=0.81 \mathrm{G}=39.8 \mathrm{~F}=141.2$ \\
\hline Rhine & $\mathrm{Y}=-269.8+0.59 \cdot \mathrm{X}_{\mathrm{a}}+0.17 \cdot \mathrm{Y}_{\mathrm{p}}+1066 \cdot \ln \mathrm{X}_{\mathrm{a}} \cdot \ln \mathrm{Y}_{\mathrm{p}} /\left(\mathrm{t}_{7} \cdot \mathrm{t}_{8}\right)$ & $\mathrm{r}^{2}=0.83 \mathrm{G}=41.8 \mathrm{~F}=80.6$ \\
\hline Odra & $\mathrm{Y}=-192.6+0.241 \cdot \mathrm{X}_{\mathrm{a}}+239.5 \cdot \ln \mathrm{X}_{\mathrm{a}} \cdot \ln \mathrm{Y}_{\mathrm{p}} /\left(\mathrm{t}_{7}+\mathrm{t}_{8}\right)$ & ${ }^{\mathrm{r} 2}=0.65 ; \mathrm{G}=25.6 ; \mathrm{F}=52.1$ \\
\hline Kureyka & $\mathrm{Y}=-559.1+5.15 \cdot \ln \mathrm{X}_{\mathrm{s}} \cdot \ln \mathrm{S}_{\mathrm{n}} \cdot \ln \mathrm{Y}_{\mathrm{p}}+0.1 \cdot\left(\mathrm{t}_{9}+1\right) \cdot \mathrm{x}_{9}$ & $\mathrm{r}^{2}=0.82 ; \mathrm{G}=35.3 ; \mathrm{F}=46.3$ \\
\hline Karabula & $\mathrm{Y}=7.0+0.2 \cdot \mathrm{X}_{\mathrm{s}} \cdot \mathrm{X}_{\mathrm{w}} /\left(\mathrm{t}_{5} \cdot \mathrm{t}_{7}\right)+5.2 \mathrm{t}_{9}$ & $\mathrm{r}^{2}=0.47 \mathrm{G}=16.7 \mathrm{~F}=15.7$ \\
\hline Erba & $\mathrm{Y}=65.1-0.98\left(\mathrm{t}_{5}+\mathrm{t}_{6}+\mathrm{t}_{7}\right)$ & $\mathrm{r}^{2}=0.28 \mathrm{G}=5.8 \mathrm{~F}=4.4$ \\
\hline
\end{tabular}




\section{Figures}

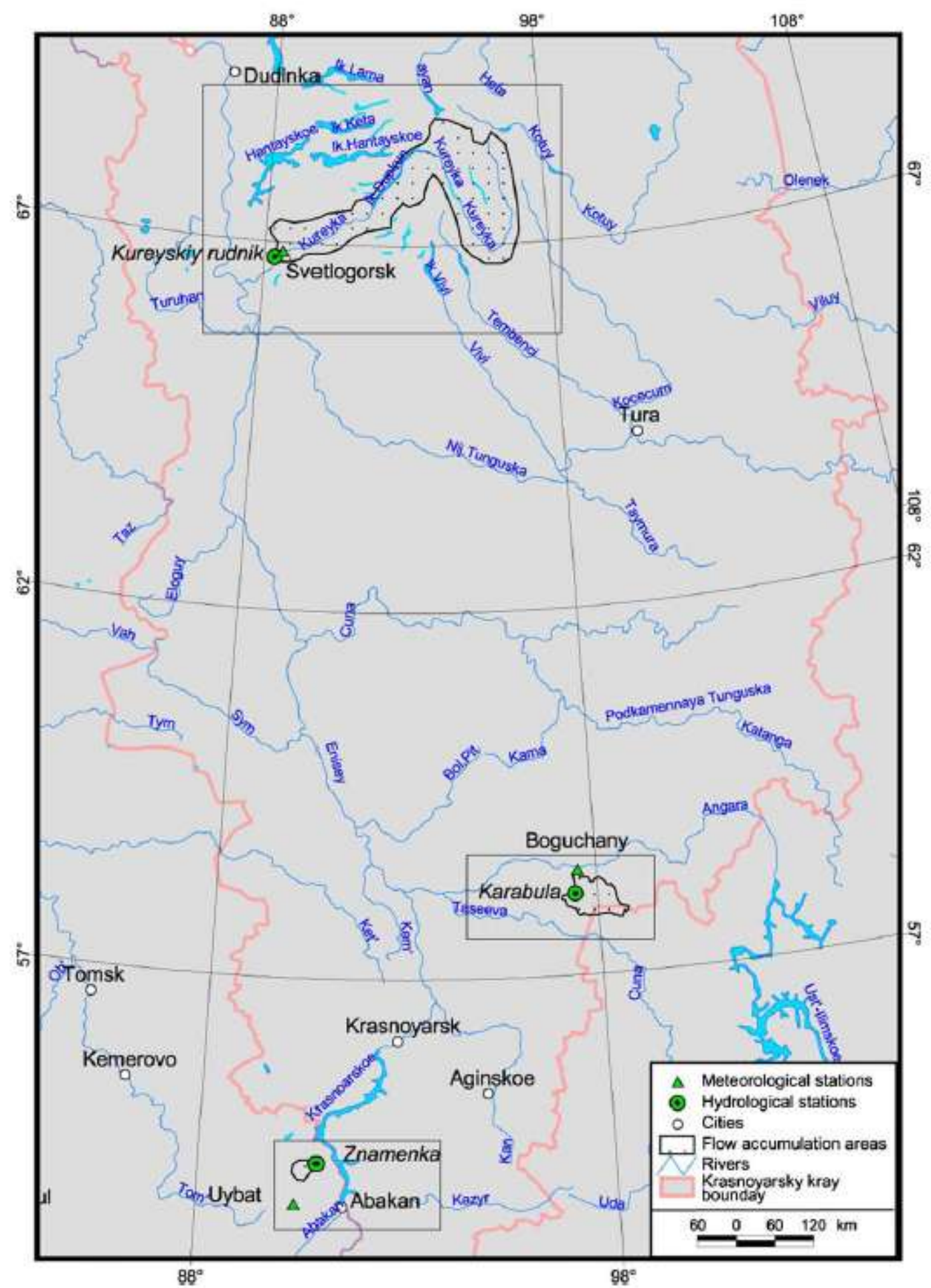

Figure 1: Catchment locations of the Kureyka, Karabula and Erba in Krasnoyarsk Kray, Siberia. 


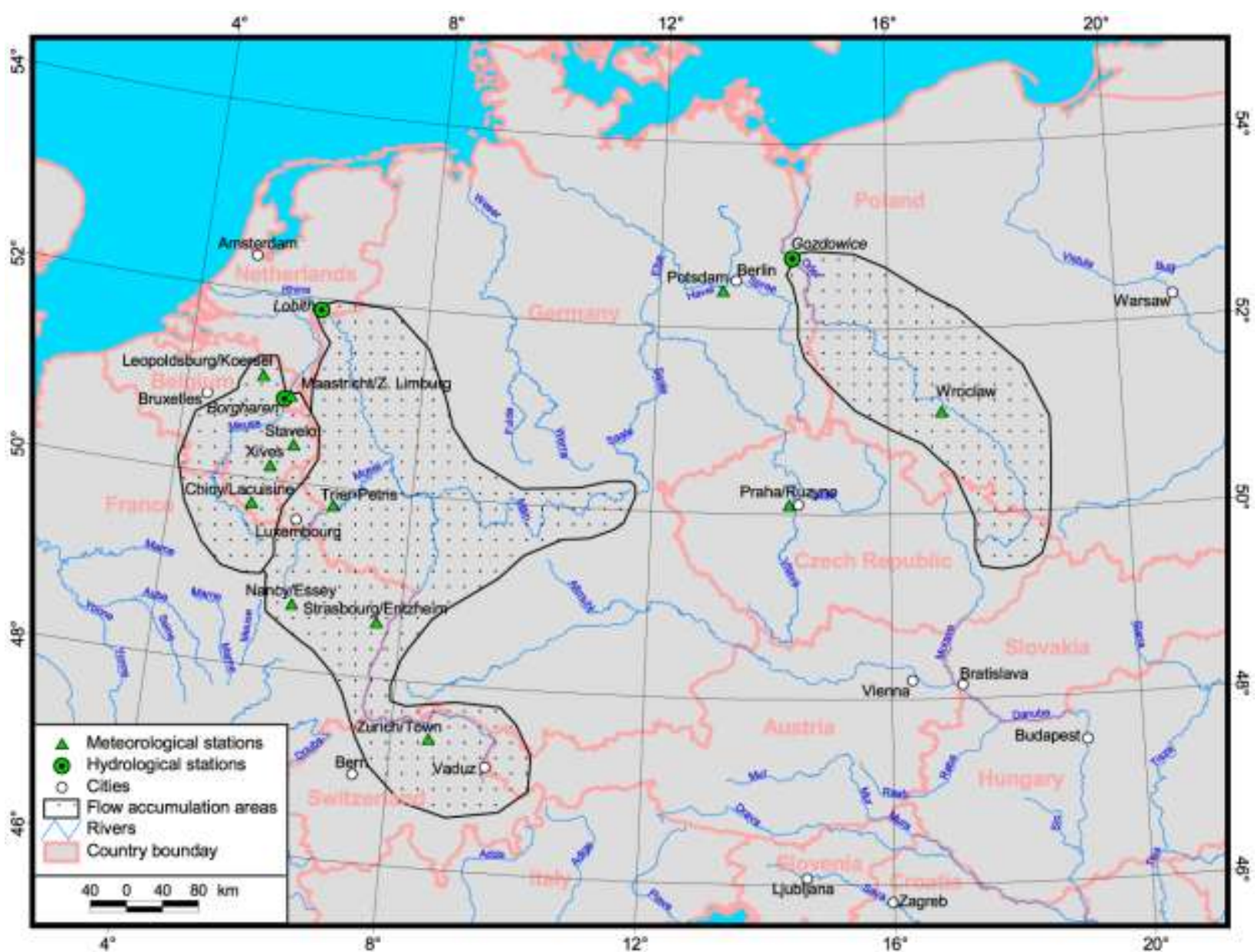

Figure 2: Catchment locations of the Rhine, Maas and Odra. 


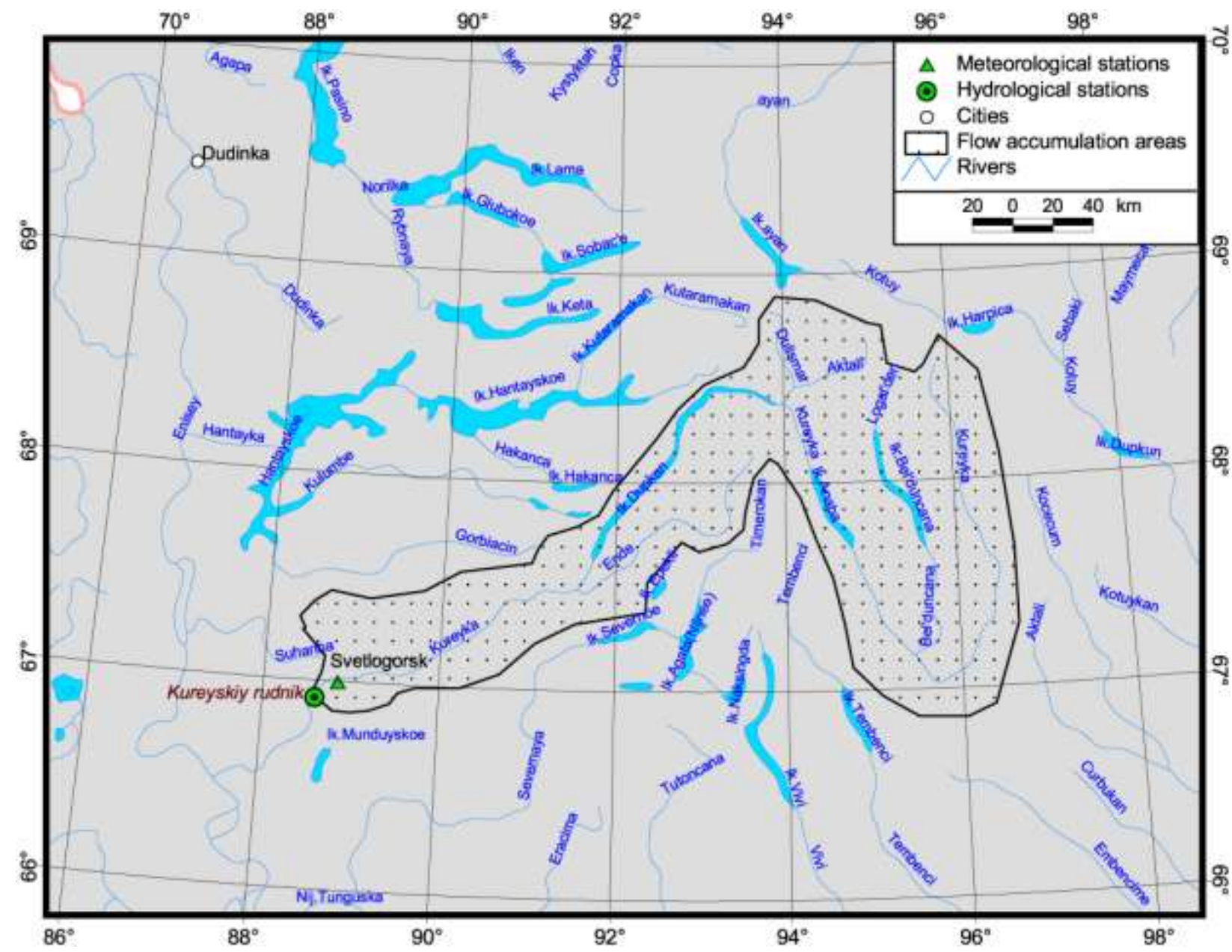

Figure 3: Catchment of the river Kureyka. 


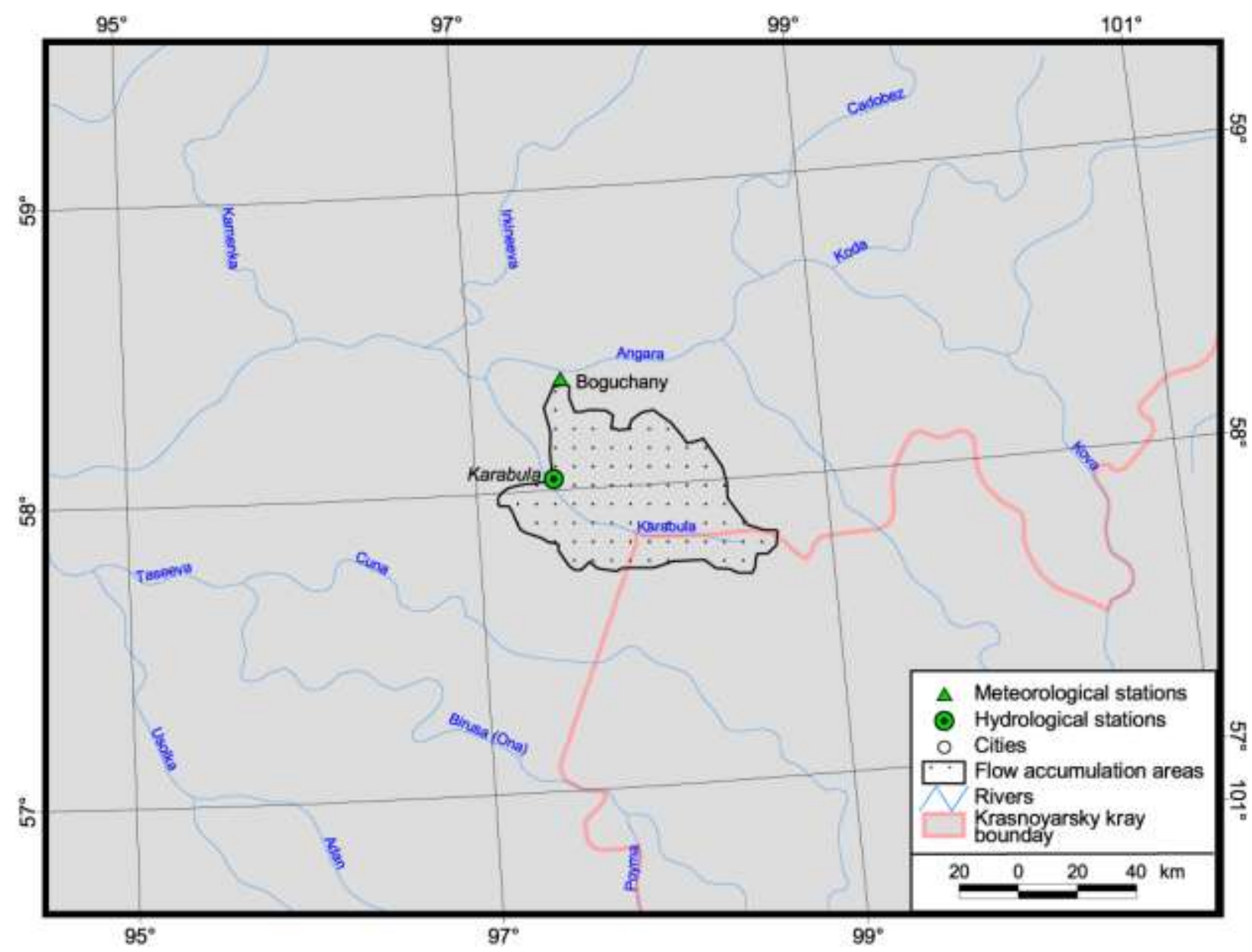

Figure 4: Catchment of the river Karabula.

30 


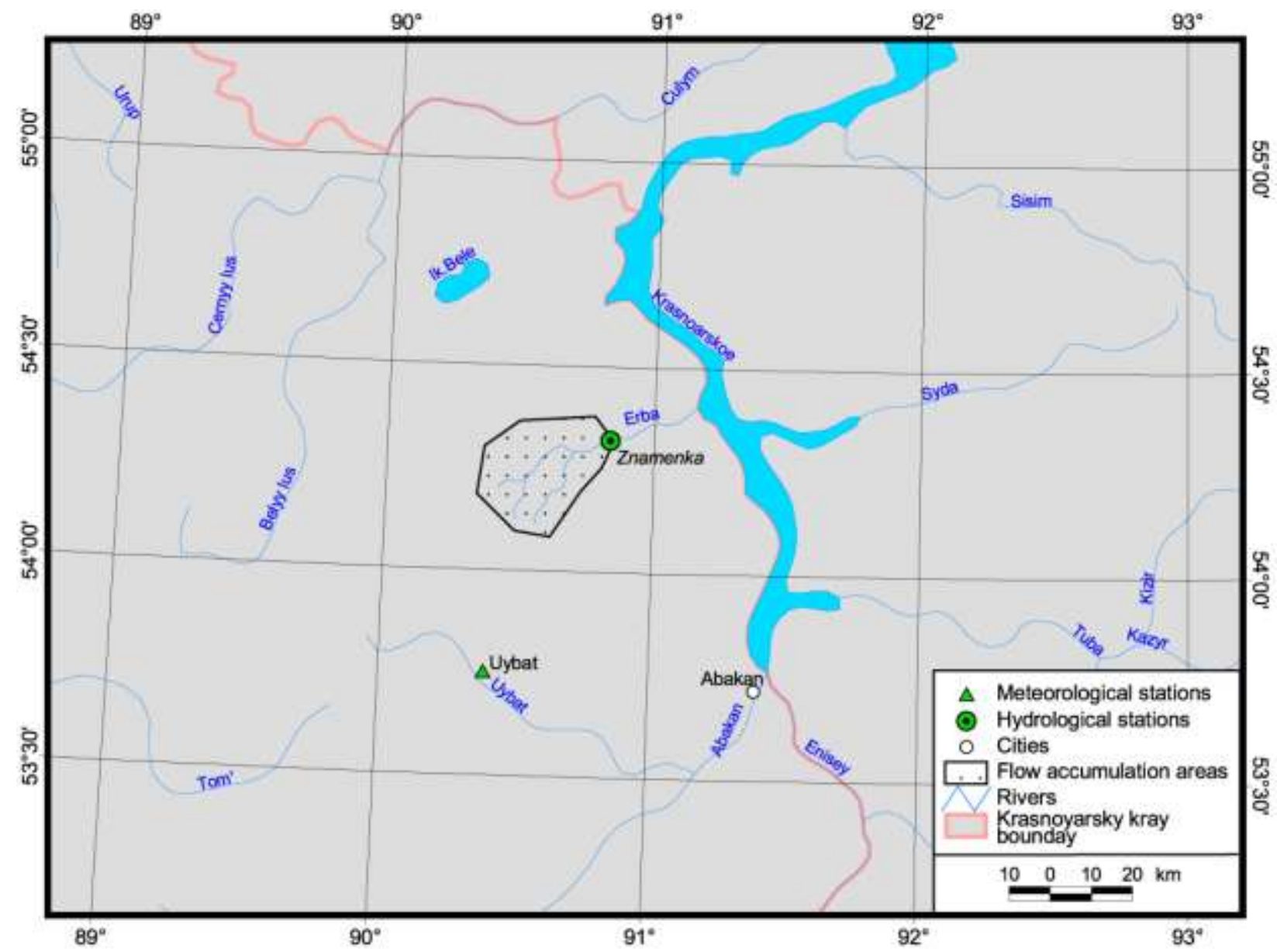

Figure 5: Catchment of the river Erba. 

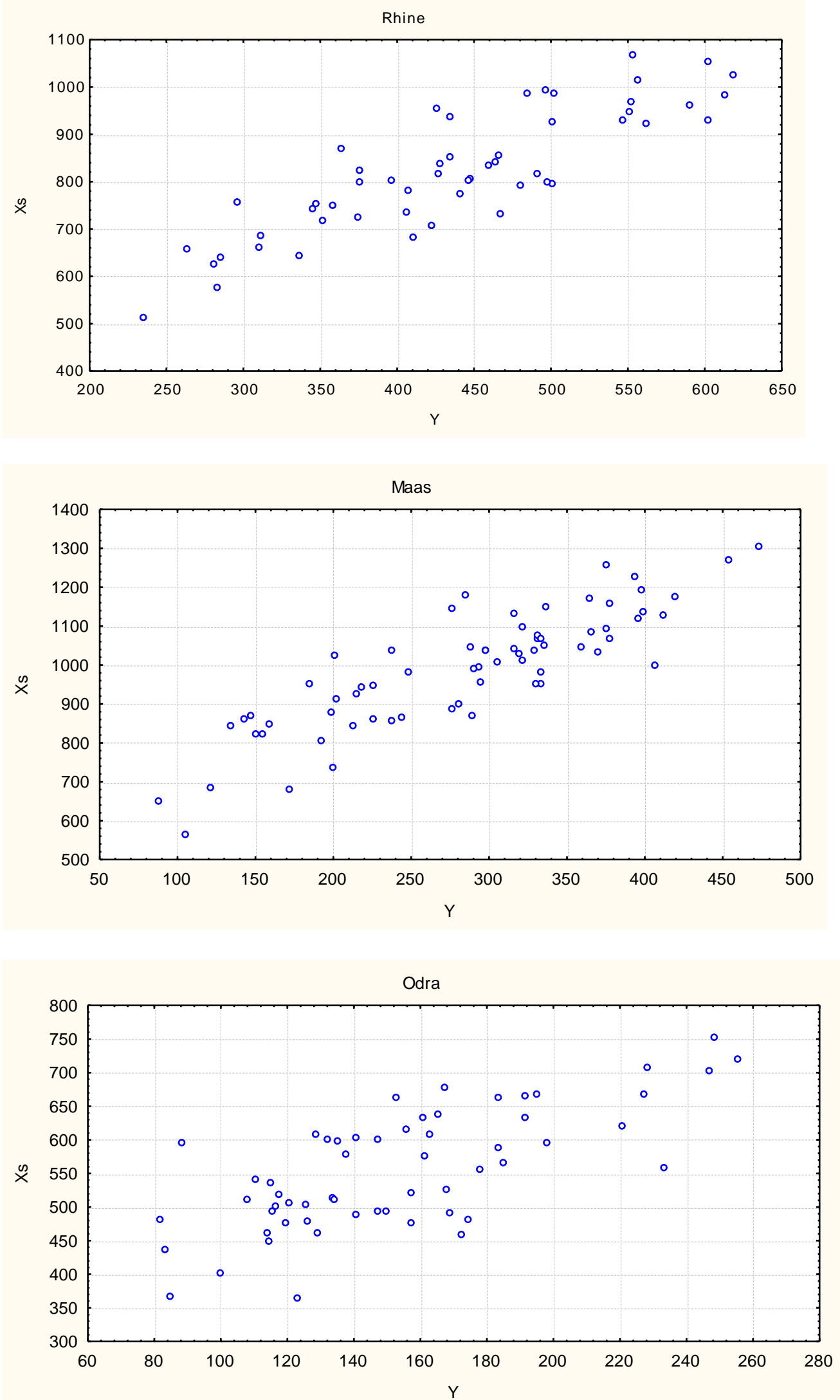

Figure 6: Scatterplot of runoff $(\mathrm{Y}, \mathrm{mm})$ and precipitation $(\mathrm{Xs}, \mathrm{mm})$ for the European rivers. 

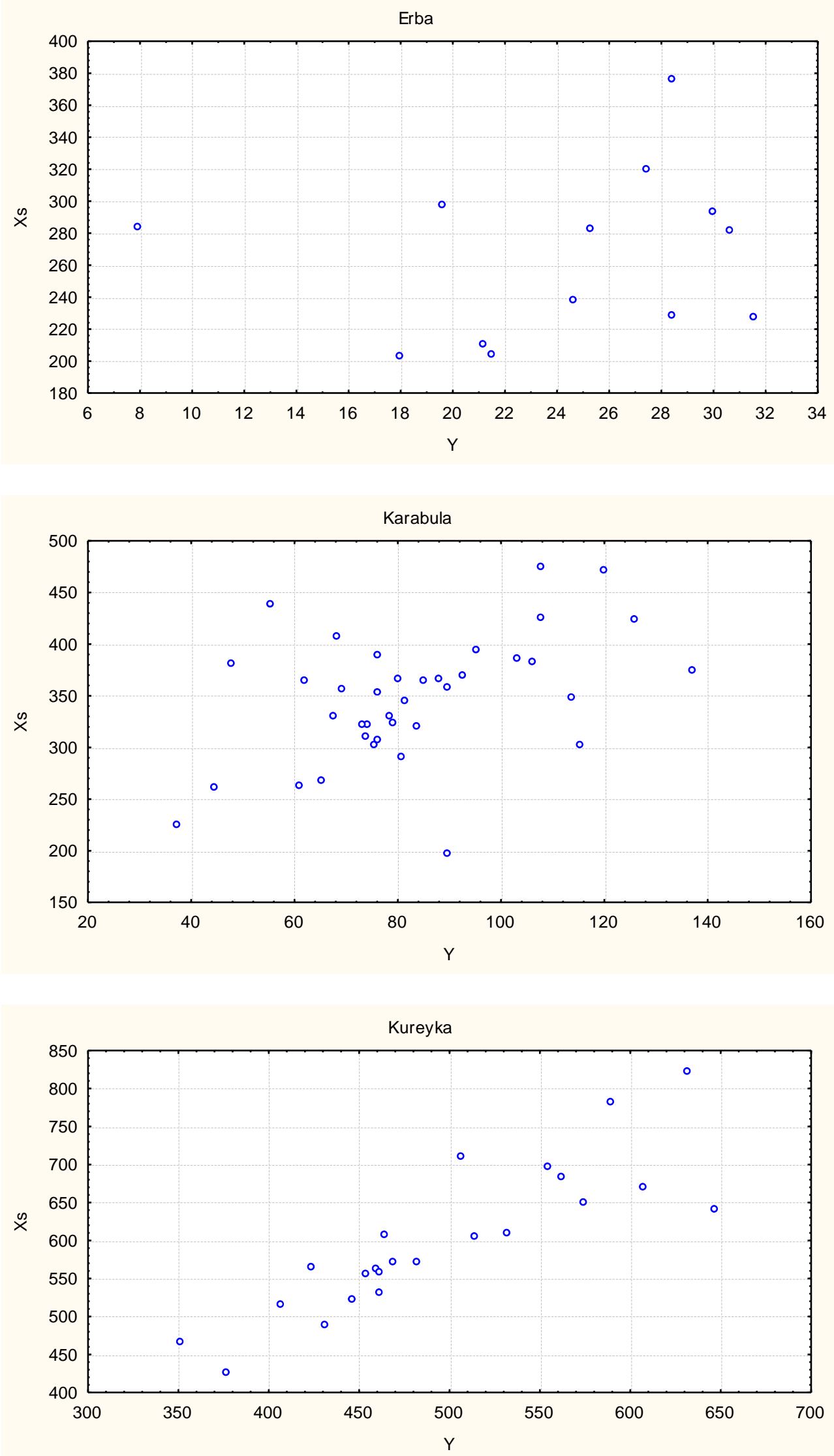

Figure 7: Scatterplot of runoff $(\mathrm{Y}, \mathrm{mm})$ and precipitation $(\mathrm{Xs}, \mathrm{mm})$ for the Siberian rivers. 

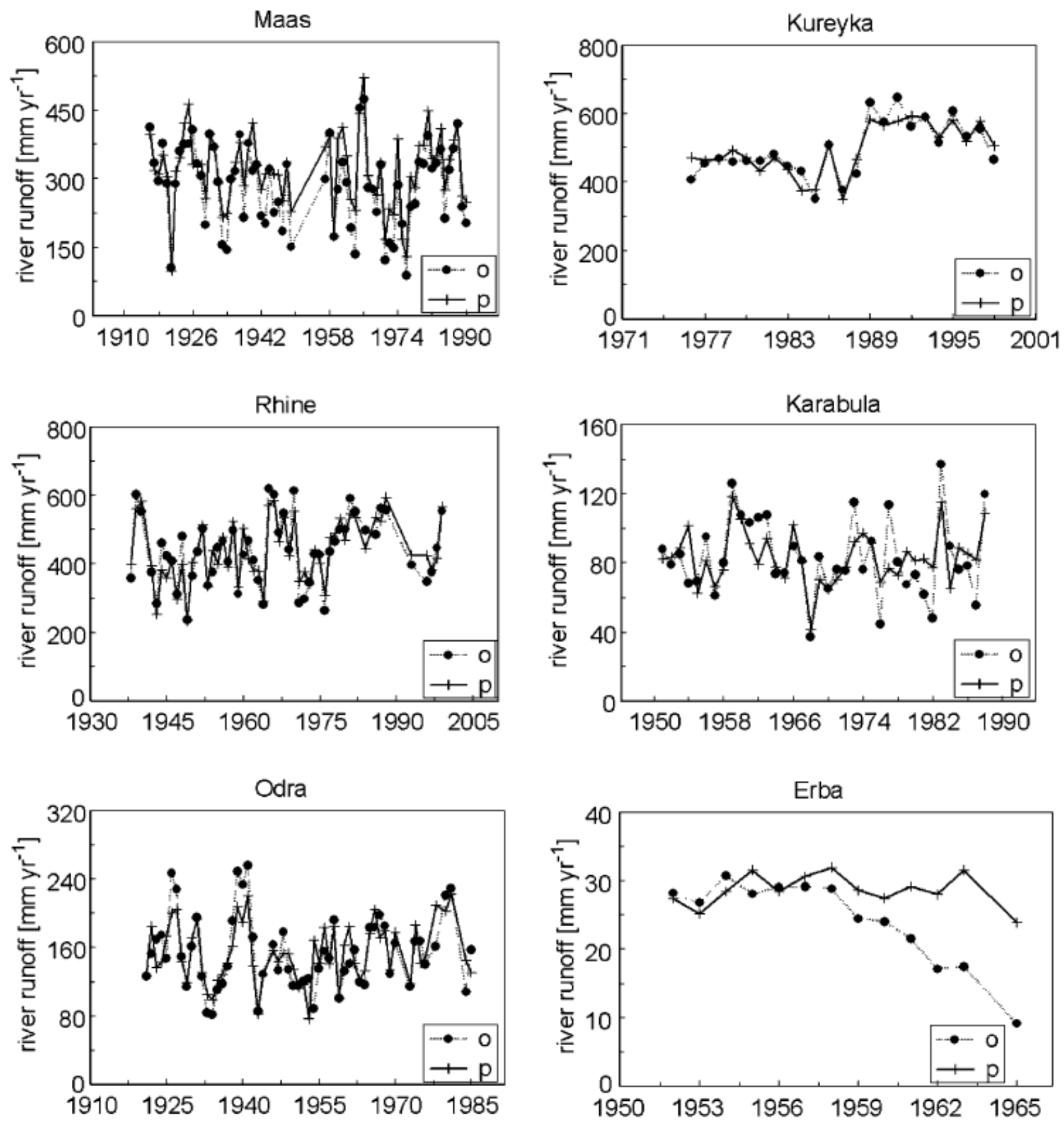

Figure 8: Predicted (p) and observed (o) annual river runoff of the six rivers. Predictions are based on the models in Table 2.

Maas incl. $t$

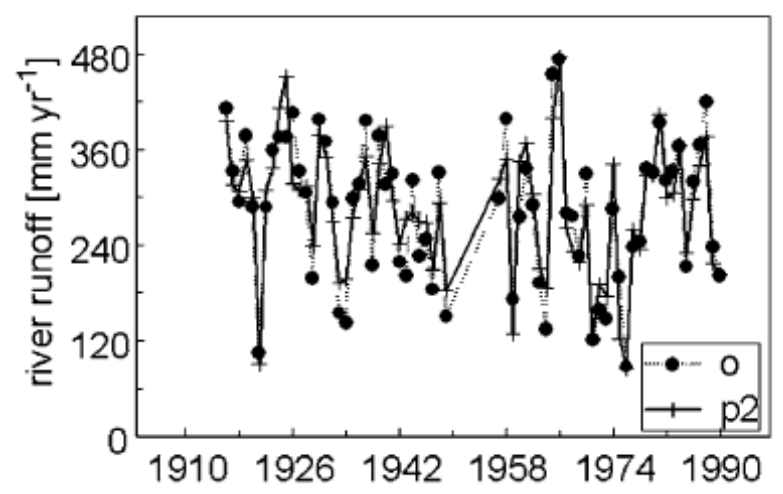

Erba with $\mathrm{t}$

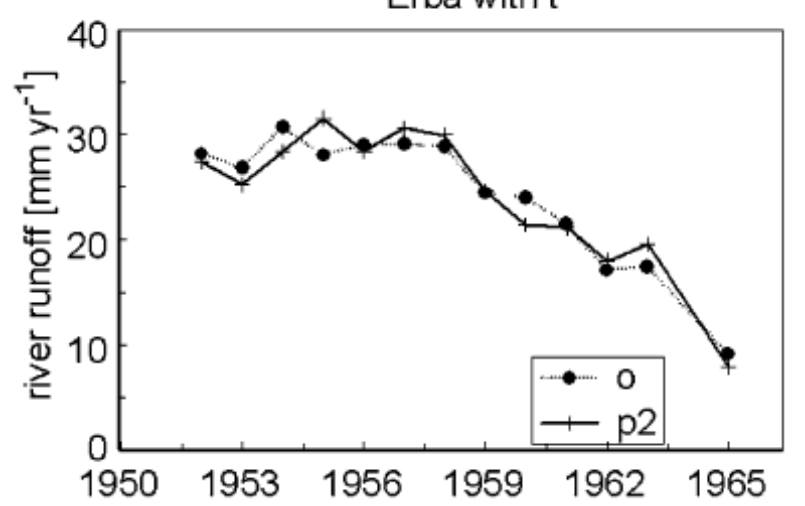

Figure 9: Predicted (p) and observed (o) annual river runoff of the Erba and Maas when time is included as a regressor. Predictions are based on the models in eq. (1) and (2). 
A

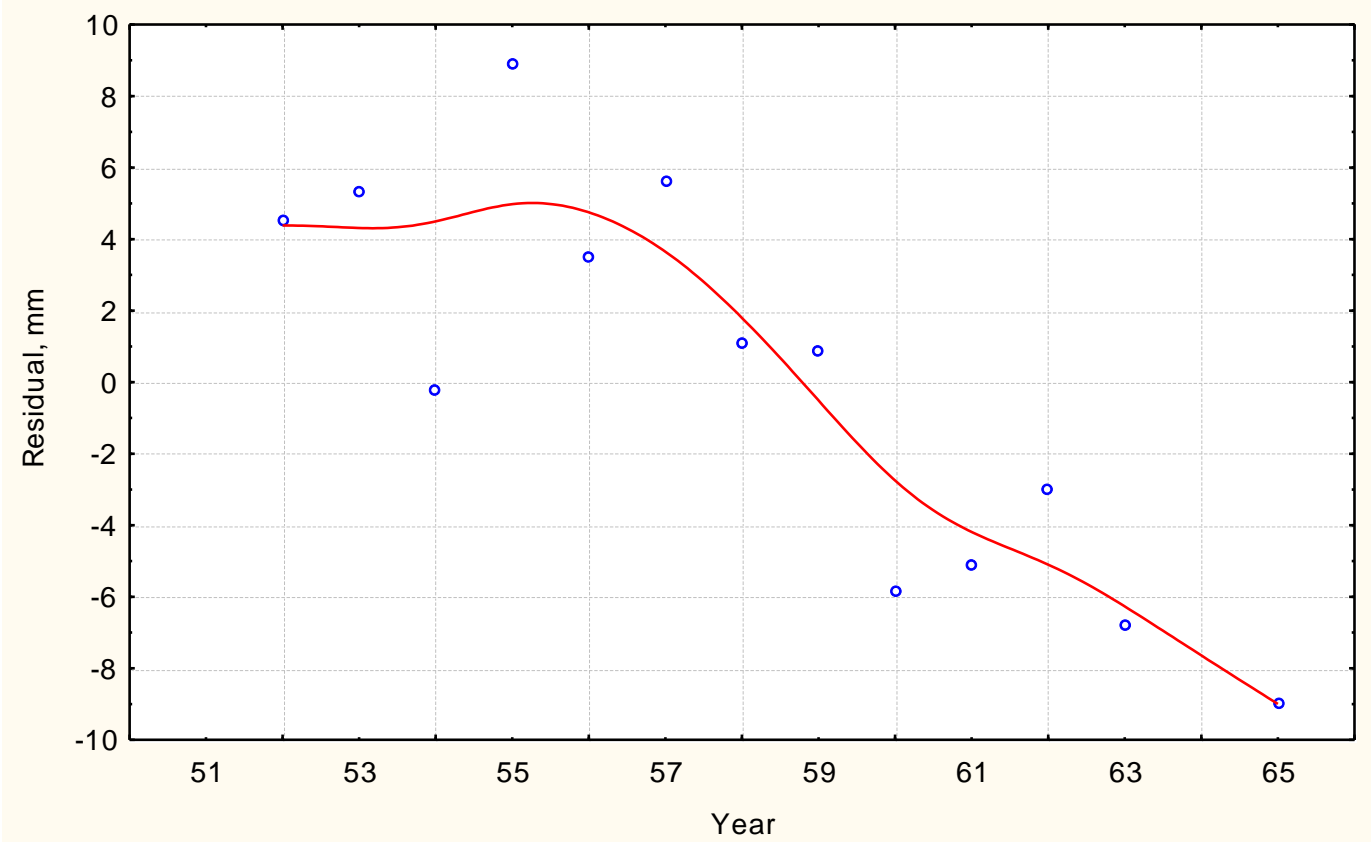

B

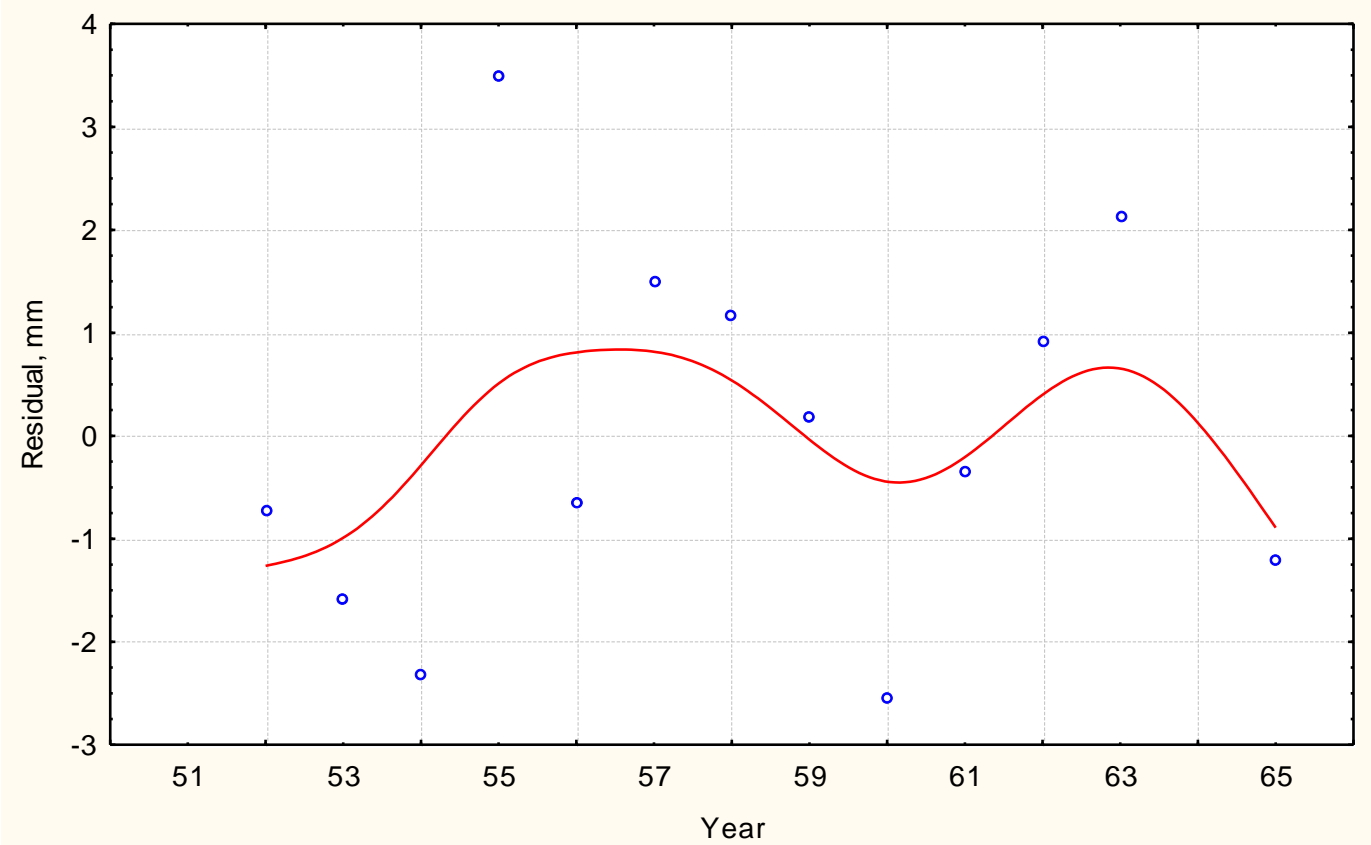

Figure 10: Plots of residuals of the models for the river Erba. (a) time factor not used in model; (b) time factor used in model. 